\title{
Framework for Incorporating Climate Change on Flood Magnitude and Frequency Analysis in the Upper Santa Cruz River
}

\author{
Jennifer G. Duan ${ }^{1}$, Yang Bai ${ }^{1}$, F. Dominguez ${ }^{2}$, E. Rivera ${ }^{2}$, Thomas Meixner ${ }^{3}$ \\ ${ }^{1}$ Department of Civil Engineering and Engineering Mechanics, University of Arizona, \\ Tucson, Arizona, USA. \\ ${ }^{2}$ Department of Atmospheric Sciences, University of Illinois, Urbana-Champaign, Illinois, \\ USA. \\ ${ }^{3}$ Department of Hydrology and Water Resources, University of Arizona, Tucson, Arizona, \\ USA
}

\section{Abstract}

Hourly precipitation for one historical (1991-2000) and two future periods (20312040 and 2071-2079) were generated using the Weather Research and Forecasting (WRF) Regional Climate Model (RCM). The climate simulations were conducted for the Southwest region of the United States using an hourly temporal and $10 \mathrm{~km}$ spatial resolution grid. The boundary forcing for the WRF model was developed by the Hadley Centre for Climate Prediction and Research/Met Office's HadCM3 model with A2 emission scenario. The precipitation from the RCM-WRF model was bias-corrected using the observed data, and then used to quantify the impact of climate change on the magnitude and frequency of flood flow in the upper Santa Cruz River watershed (USCRW) in southern Arizona. The Computational Hydraulics and River Engineering two-dimensional (CHRE2D) model, a two-dimensional hydrodynamic and sediment transport model, was adapted for surface flow routing. The CHRE2D model was first calibrated using a storm event on July $15^{\text {th }}, 1999$, and then applied to the watershed for three selected periods. The simulated annual maximum discharges in two future periods were added to the historical records to obtain the flood frequency curve. Results indicate 
the peak discharges of 100-year, 200-year, and 500-year flood only increased slightly, and the increase is within the $90 \%$ confidence interval limits. Therefore, the flood magnitude and frequency curve will not change with the inclusion of projected future climate data for the study watershed.

Keywords: hourly precipitation; watershed model; flood frequency; flood intensity.

\section{Introduction}

Flood magnitude and frequency are essential for both hydraulic structures and flood risk management. The World Disaster Report (IFRCRCS, 2012) found that flooding is the leading disaster accounting for approximately 55\% of all the natural disasters. Flood magnitude and frequency will change as climate changes. From the analysis of precipitation projections from eight Global Climate Models (GCMS) (Shamir et al. 2015), the Southwest US will see more dry summers and less wet ones. Dominguez et al. (2012) found a decrease in the mean winter precipitation of approximately $7.5 \%$ in the Southwestern US. However, the maximum area-averaged daily precipitation in the winter will increase $12.6 \%$ and $14.4 \%$ for the return periods of 20 years and 50-years, respectively. The precipitation changes require the re-analysis of flood frequency curve, which traditionally derived from the limited historical records.

Flood frequency studies (Booij, 2005; Chen and Grasby, 2014; Leonard et al., 2008; Mirza et al., 2003; Raff et al., 2009; Li et al. 2013) in different regions of the world showed that the impacts of climate change on flood magnitude and frequency vary regionally due to local climate and watershed characteristics (e.g., elevation, location). Estimated flood flows from hydro-climate models are often used together with historical 
records for flood risk analysis (Shamir et al. 2015; Booij, 2005; Chen and Grasby, 2014; Leonard et al., 2008; Mirza et al., 2003; Raff et al., 2009; Li et al. 2013). All of these studies used the precipitation output from climate models as the input to hydrologic models for surface flow routing. Either lumped or distributed hydrological models were chosen to compute surface runoff and stream flow and their spatial and temporal distributions.

To route surface flow in a watershed with complex terrains, a hydrodynamic model capable of simulating stream flow as well as overland flow is required ( $\mathrm{Yu}$ and Duan, 2016, Yu and Duan, 2014). Many hydrological models for simulating stream flow are based on the solutions of kinematic wave (Vivoni et al., 2007) or diffusion wave (Qu and Duffy, 2007) equations. Both the kinematic and diffusion wave equations are simplifications of the shallow water equations. Singh (2002) have studied the limits and accuracies of these equations. Recent research (Yu and Duan, 2014) showed that the simplified models can yield inaccurate predictions of peak flow in streams. Yu and Duan (2012, 2014, 2016) developed the CHRE2D model based on the solutions of shallow water equations and the kinematic wave approximation for surface flow routing in a watershed. The model takes the raw DEM data as the input, and is capable of simulating surface flow routing over complex irregular terrains. In this paper, the CHRE2D model was used to route the hourly precipitation data for the historical (1991-2000) and future periods (2031-2040, 2071-2079) in the USCRW.

The precipitation output from GCMs has commonly been used to investigate the impact of climate change on flood risk (Merritt et al., 2006; Dominguez et al., 2009; Geil et al., 2013). GCMs participating in phase 3 of the Coupled Model Intercomparison 
Project (CMIP3) typically have a resolution of approximately $103-455 \mathrm{~km}$, while the newer CMIP5 models range between 68 to $342 \mathrm{~km}$ (Flato et al., 2013). Because of the coarse spatial resolution of GCMs and the uncertainty of their precipitation output at a fine temporal resolution, the results from GCMs are not suitable for direct flood modeling (Kay et al., 2006a, b). A high resolution RCM embedded within a GCM will provide the output at a finer scale resolution, which can be used to assess the impact of climate change on stream flow. Since HadCM3 provides the most realistic boundary conditions for simulating summer precipitation in the Southwest (Shamir et al., 2015), it is used as the forcing boundary to the RCM. WRF-RCM was then operated to predict future precipitation. WRF-HAD was found to have relatively large wet biases in the study area (Shamir et al., 2015), therefore, a bias-correction procedure was applied to remove these biases.

The common precipitation input data for hydrological models are the daily or monthly average precipitation, which result in the daily or monthly averaged flow in the river. However, the design of hydraulic structures requires the peak discharge, such as 100-year flood flow for bridge design. The daily averaged flow can be much less than the peak flow in the Southwest because of the short duration and high intensity of storm events. Hanel and Buishand (2010) found the increase in the large quantiles of the daily maxima was much smaller than that in the quantiles of the hourly maxima at the end of $21^{\text {st }}$ century. Therefore, hourly precipitation from the RCM was used in this study. Hourly precipitation was bias corrected, and then used as input to the CHRE2D model to simulate surface flow. 
The objective of this paper is to quantify the changes of flood magnitude and frequency caused by climate change in the USCRW. Instead of using a simplified hydrological model, an advanced hydrodynamic model, CHRE2D, was used. The precipitation generated from the WRF regional climate model was routed through the watershed. Three periods were simulated: the historical period of 1991-2000, the future periods of 2031-2040 and 2071-2079. In particular, we applied the event-based bias correction method to precipitation in all three periods, calibrated the CHRE2D model using a summer event, and verified the modeling results using 39 observed storm flows in the historical (1991-2000) period. The calibrated model was applied to simulate storm events in two future periods for developing the new flood magnitude and frequency curve.

\section{Data Source}

\subsection{The Study Site}

The Santa Cruz River Watershed (SCRW), located in south central Arizona (Figure 1), is a transboundary watershed at an elevation ranging from 668.12 to $2,845.92$ m. The Santa Cruz River (SCR) is an ephemeral river that drains into the Gila River, a tributary to the Colorado River (Shamir et al., 2007). The SCR flows to the South and makes one 40.22 kilometer loop through Mexico before re-entering the United States at nearly 5 miles from Nogales, Arizona. Then, the river flows northward to its confluence with the Gila River. The study area is the upper Santa Cruz River watershed encompassing the reach of the SCR within the US, approximately 4,000 square kilometers. The largest tributary to this reach is the Rillito River in Tucson, Arizona. The topographic data were from the LIDAR survey in 2005 by the Pima County Regional Flood Control District. Although the LIDAR data have a fine grid resolution, the 
computational cell was obtained by aggregating the LIDAR data to $100 \mathrm{~m} \times 100 \mathrm{~m}$ cell. The simulation domain is approximately $40,000 \mathrm{~m} \times 100,000 \mathrm{~m}$, so the total number of cells is 400,000 .

In the SCRW, the mean monthly precipitation in the summer is greater than that in the winter (Wood et al., 1999). Winter and summer are the major sources of precipitation, and spring and fall are usually dry. The mean annual precipitation from 1914 to 2000 at the Nogales gauge located at the upper SCRW was $422 \mathrm{~mm}$, consisting of an average $59 \%$ in the summer and $29 \%$ in the winter (Shamir et al., 2007). Figure 2 shows the monthly averaged streamflow from 1940 to 2013 at the Cortaro gauge at the downstream of the study reach. The summer rainy season is typically from July to September, and sometimes extends to October. The winter rainy season is from November to March, and flow is much smaller than that in the summer. Figure 3 shows the annual peak discharges at the Cortaro gauge, and the different symbols represent the season when the peak discharge was observed. One can find most of the peak flow events (about $81.25 \%$ ) occurred in the summer, and only a few (about 15.63\%) in the winter. In the past 74 years, only two annual peak flow events were observed in the fall, October 1973 and October 1983, respectively. In 2000, the second largest annual event occurred in October. Although a flood event in the study site most likely occur in the summer, several large events were seen in the fall. Therefore, we selected a typical rainfall event between 1991 and 2000 to calibrate the surface flow model. Then, the calibrated model was verified by selected events from all four seasons.

\subsection{Climate Data Source}


Historical and future climate projections at the global scale were used as the forcing data for the regional climate model. The forcing data was obtained from the HadCM3 (Gordon et al., 2000; Pope et al., 2000) model with A2 emission scenario for 43 vertical levels at an approximate horizontal resolution of $3.75^{\circ}$ by $2.5^{\circ}$. The HadCM3 global data was used as forcing for the Advanced Research Version (ARV) of the WRF regional climate model (Skamarock et al., 2005). The model was run continuously for 111 years at $35 \mathrm{~km}$ resolution over a large domain that encompasses the United States and northern Mexico, and the model output was stored in every six hours. WRF single-moment three-class microphysics (Hong et al., 2004), Kain-Fritsch cumulus parameterization (Kain and Fritsch, 1993), Goddard shortwave radiation (Chou and Suarez, 1994), Rapid radiative transfer model (RRTM), longwave (Mlawer et al., 1997), Eta surface layer (Janjić, 1996, 2002), Mellor-Yamada-Janjić (MYJ) planetary boundary layer (Janjić, 1990, 1996, 2002), and the Noah land surface model Version 1.0 (Chen and Dudhia, 2001) were used. The WRF model (Skamarock et al., 2005) was used in a two-step downscaling simulation. The first step used $35 \mathrm{~km}$ and $6 \mathrm{~h}$ resolution over the contiguous U.S. Then, using the 35 $\mathrm{km}$ WRF data as the lateral boundary conditions, a second one-way downscaling was performed at $10 \mathrm{~km}$ and 1 hour resolution over a smaller domain $\left(28^{\circ}-37^{\circ} \mathrm{N}, 105^{\circ}-116^{\circ}\right.$ W) covering the State of Arizona (Figure 1c) for three time periods: current (1991-2000), near future (2031-2040), and far future (2071-2079). As described in Wi et al. (2012), the same modeling physics was used for both simulations except for the spectral nudging (Miguez-Macho et al., 2005) method in the first step for retaining the synoptic-scale variability of the HadCM3 model. Details of the simulations and comparisons with observations over the southwestern U.S. were reported in Wi et al. (2012). 
The $10 \mathrm{~km}$ simulations for the historical period (1991-2000) [WRFhad10] were compared with the available climatology from the 'North American Regional Reanalysis' (NARR) for the period (1979-2007) that was used as observations. The results were also compared with the $50 \mathrm{~km}$ NARCCAP data (Mearns et al. 2009). The comparisons showed the NARCCAP models $(50 \mathrm{~km})$ generally overestimate precipitation for all seasons except for the summer, and the results have both positive and negative biases (Fig 4). The $10 \mathrm{~km}$ simulation generally has smaller biases, except in the spring, when the model is within the NARCCAP biases. However, the spring season showed larger biases because it is climatologically the driest period of the year. As to the intensity and duration of individual storm event, the WRF model overestimates the frequency of high-intensity events, and underestimates the frequency of lower intensity events when compared to observations in the summer. In the winter, WRF overestimates the frequency of lower intensity events and underestimates the high frequency event. Therefore, the $10 \mathrm{~km}$ gridded hourly precipitation data from the WRF model needs bias-correction prior to use in a hydrological model.

\subsection{Bias Correction of Precipitation Data}

Bias-correction is traditionally used for correcting the biases in daily or monthly precipitation distributions (Fowler and Kilsby, 2007; Piani et al., 2010; Yang et al., 2005). The quantile-based mapping method is commonly used for correcting biases in monthly precipitation (Wood et al. 2002). However, the bias-correction method applicable to monthly precipitation is insufficient for highly variable hourly data (Shamir et al.2015). In order to capture peak flows using a hydrological model, hourly precipitation should be bias-corrected and used as the input. Therefore, we propose a rainfall event-based quantile mapping method to correct the bias in hourly precipitation. The rainfall events at 
each season are driven by different storm types, and thus yield different stream flows (Shamir et al. 2015). We assume hourly precipitation in each season has an unique intraannual distribution. The observed hourly precipitation distributions of rainfall events were used to correct the bias in the projected ones in the same season. The bias-correction was applied to each cell in the study domain.

\subsubsection{Bias-correction for the Historical Period}

Figure 5 explains the bias correction procedure for the period 1991-2000. First, the downscaled WRF hourly precipitation data with a resolution of 10-km was re-gridded to $1 / 8$-degree resolution to be consistent with the observed hourly precipitation obtained from the North American Land Data Assimilation System (NLDAS-2, http://ldas.gsfc.nasa.gov/nldas/NLDAS2forcing.php). The bias-correction was applied at each cell, respectively, for a total of 45 cells in the study area (Figure 6). Second, the ten years continuous hourly precipitation from 1991 to 2000 was divided into four seasons: spring (April-June), summer (July-September), fall (October) and winter (NovemberMarch). The rainfall events in each season were grouped into a series for each cell, and the bias-correction was applied at each cell for each season.

Third, we counted each series of continuous non-zero precipitation as a rainfall event. To distinguish an independent event, an appropriate minimum inter-event time (IET) has to be identified. Driscoll and Consultants (1989) analyzed 160 rainfall gage records from 1949 to 1987 throughout the US, and suggested an IET value of six hours in Arizona. We used this criterion to identify each independent rainfall event, and then calculated the total rainfall volume (in $\mathrm{mm}$ ) for each event. Afterward, all the events with 
total volume greater than $0.01 \mathrm{~mm}$ were ranked in a descending order according to the rainfall volume for each season. Based on this rank, each event was assigned a nonexceedance percentile. The same procedure was repeated for the observed rainfall events in the historical period 1991-2000. For example, there are 613 rainfall events with total volume greater than $0.01 \mathrm{~mm}$ for the entire historical period at cell $\# 1$ in the summer. These events were sorted in a descending order, and each was assigned a non-exceedance percentile according to the total rainfall volume. Then, we compared the WRF simulated rainfall events at a given season with the observed ones. The bias-correction was applied to the projected events based on the observed ones having the same non-exceedance percentile. The scaling factors were calculated as the multiplicative anomalies in Eq. (1).

$$
\begin{gathered}
M_{i, q}^{\text {hist }}=\frac{P_{i, q}^{o b s}}{P_{i, q}^{w r f}} \\
\left(P_{i, q}^{w r f}\right)_{C}=P_{i, q}^{w r f} M_{i, q}^{\text {hist }}
\end{gathered}
$$

where $P_{i, q}^{o b s}$ and $P_{i, q}^{w f}$ are the $q^{\text {th }}$ quantile of the observed and the WRF model simulated total volumes of rainfall during 1991-2000, respectively; subscript $i$ represents the seasons (spring, summer, fall, winter); $M_{i, q}^{\text {hist }}$ is the scaling factor of the historical period, representing the $q^{\text {th }}$ quantile multiplicative anomaly of the corresponding rainfall event.

In Step 7, the projected rainfall volume from each event for the current period was bias-corrected using Eq. (2). $\left(P_{i, q}^{w r f}\right)_{C}$ is the bias-corrected rainfall volume for the $q^{\text {th }}$ quantile event. Upon knowing the rainfall volume for an event, Shamir et al. (2015) pointed out three requirements for developing hourly precipitation distributions: the duration between events, the distribution of duration hours, and the magnitude of hourly 
precipitation. Although the rainfall volume of each event has been bias-corrected, the projected hourly precipitation distributions also need to be bias-corrected to satisfy these three requirements. The observed hourly precipitation of rainfall events during 19912000 were used to correct the bias of the WRF model projected events. Each projected event was matched with an observed one of the same non-exceedance frequency. The hourly precipitation of the projected event was compared with the corresponding observed event. If a mismatch was found, the projected hourly precipitation was replaced by the observed one. After correcting all the WRF projected events, the bias-corrected hourly precipitation distributions were placed back into the original series of hourly precipitation for that season. The same procedure was applied to all the other cells in the study area. Hourly precipitation data for each cell were then aggregated to obtain the bias-corrected accumulated daily and monthly precipitation.

\subsubsection{Bias-correction Results for the Historical Period}

This section discusses the comparison of the WRF simulated, bias-corrected and observed precipitation. There are a total of 45 cells with observed precipitation in the study domain (Fig.6). The observed and simulated precipitation events for the historical period, 1991-2000, are slightly different at each cell, but have the same order of magnitude (Table 1). To illustrate the results from bias-correction, a typical cell, cell 33, was selected. The cumulative distribution functions (CDF) of the event total rainfall volumes for the period 1991-2000 shows significant differences for the spring, summer and fall seasons between the WRF simulated and the observed, especially for the events of large cumulative probabilities (Fig.7). The WRF simulated results overestimated the event total rainfall volumes, but the bias-corrected results matched perfectly with the 
observations for all the seasons. The bias-corrected maximum event total rainfall volumes are $12.5 \mathrm{~mm}, 42.76 \mathrm{~mm}, 27.27 \mathrm{~mm}$ and $60.3 \mathrm{~mm}$ for the spring, summer, fall and winter seasons, respectively. Figure 8 shows the CDFs of rainfall events duration for period 1991-2000. The WRF simulated results have been significantly improved after the biascorrection for the spring season. The bias-corrected rainfall durations matched well with the observations for all the seasons.

Mean monthly precipitation for each season was also calculated cell by cell. For example, the mean monthly precipitation in the summer was obtained by calculating the average of July, August and September monthly precipitation of the entire historical period at each cell (Figure 9). Bias-corrected mean monthly precipitation matched well with observations for all seasons. The WRF simulated results overestimated the monthly precipitation in the spring and summer seasons, and the bias correction significantly improved the results. For the winter season, the WRF simulated results underestimated precipitation. The results show that the WRF projected precipitation, from the hourly to the monthly scale, have been improved significantly after the bias-correction (Fig.7, 8, 9).

The scaling factors calculated from Eq. (1) were used to correct the biases of all the events in the future periods: 2031-2040 and 2071-2079. The scaling factors were applied to two future periods to calculate the bias-corrected rainfall volume for each event as:

$$
\left(P_{i, q}^{f u t}\right)_{c}=P_{i, q}^{f u t} M_{i, q}^{\text {hist }}
$$

The bias-corrected precipitation is the input to the hydrodynamic model for simulating surface flow. Because of infiltration, small rainfall events with the total 
rainfall volume less than $10 \mathrm{~mm}$ were neglected because they only generate negligible runoff. After this screening, 76 events in 2031-2040 and 76 events in 2071-2079 were selected. The durations of rainfall events for the periods 2031-2040 and 2071-2079 are ranging from 10 to $73 \mathrm{hrs}$ and 9 to $39 \mathrm{hrs}$, respectively. The medium durations for these two periods are 19 and 16 hours, respectively.

\section{Watershed Model}

Surface flow routing, including overland and channel flow routing, refers to the process that precipitation generated surface runoff moves over a land surface from the source areas to an outlet. The simulation of surface flow routing in a watershed is accomplished by using either two models for overland and channel flow (Julien, et al., 1995; Qu and Duffy, 2007), separately, or one model to simulate both overland and channel flow (Cea, et al., 2010; Kim, et al., 2012). The disadvantage of using two models is discontinuity between the overland flow and the channel flow models, and the second method has challenges to integrate the simulations of overland and channel flow using one hydrodynamic model. This study used an advanced 2D hydrodynamic and sediment model, CHRE2D (Yu and Duan 2012, 2014, 2016) for simulating both overland and channel flow. CHRE2D solved the two-dimensional shallow water equations to route surface flow in a watershed. In order to increase the stability of the model, the kinematic wave approximation was used when flow depth is smaller than a threshold (e.g., $1 \mathrm{~mm}$ ).

\subsection{Model Description}

The governing equations are the two-dimensional depth-averaged shallow water equations (Fraccarollo and Toro, 1995; Garcia-Navarro et al., 1995; Zhao et al., 1994), which are a set of hyperbolic partial differential equations that describe the free surface 
flow over an irregular land surface, and can be written in the differential conservative form as:

$$
\frac{\partial \mathbf{Q}}{\partial t}+\frac{\partial \mathbf{F}}{\partial x}+\frac{\partial \mathbf{G}}{\partial y}=\mathbf{S}_{\mathbf{s}}-\mathbf{S}_{\mathbf{f}}+\mathbf{S}_{\mathbf{r}}
$$

where $\mathbf{Q}$ is the vector of conservative variables, $\mathbf{F}$ and $\mathbf{G}$ are the vectors of advective fluxes in $x$ and $y$ directions, respectively, $\mathbf{S}_{\mathrm{s}}$ is the vector of bed slope source term, $\mathbf{S}_{\mathrm{f}}$ is the vector of bed friction source term, $\mathbf{S}_{\mathbf{r}}$ is the vector of rainfall excess source term.

The kinematic wave approximation (KWA) is based on the assumption that the local acceleration and advective terms in the momentum equations are insignificant comparing to the friction and the bed slope source terms (Ponce, 1989). Therefore, the momentum equations, Eq. (4), are simplified to:

$$
\mathbf{S}_{\mathrm{s}}=\mathbf{S}_{\mathbf{f}}
$$

The shallow water equations are discretized by the Godunov-type finite volume method (LeVeque, 2002; Toro, 2009) over a regular Cartesian mesh. Using the explicit Euler scheme for the temporal derivative term, the discretized form of the governing equations can be written as (Toro and Garcia-Navarro, 2007):

$$
\mathbf{Q}^{(n+1)}=\mathbf{Q}^{(n)}-\frac{\Delta t}{\Delta A} \sum_{j=1}^{4} \mathbf{F}_{j}\left(\mathbf{Q}_{L}^{(n)}, \mathbf{Q}_{R}^{(n)}\right) \cdot \mathbf{n}_{j} L_{j}+\Delta t\left(\mathbf{S}_{0}^{(n)}+\mathbf{S}_{f}^{(n)}+\mathbf{S}_{r}^{(n)}\right)
$$

where superscript $(n)$ and $(n+1)$ refer to the variables at the current and next time step; $\Delta t$ is time step; $\Delta \boldsymbol{A}$ is the cell area; $j$ is the index of a cell edge; $\mathbf{F}_{j}\left(\mathbf{Q}_{L}, \mathbf{Q}_{R}\right)$ is the vector of Riemann flux calculated by solving a local Riemann problem normal to the 
edge $j ; \mathbf{Q}_{L}$ and $\mathbf{Q}_{R}$ are the vectors of conservative variables on the left and right side of the edge $j ; \mathbf{n}_{j}$ is the normal vector to the edge $j ; L_{j}$ is the length of the edge $j$. The local Riemann problem is solved by the Harten-Lax-van Leer (HLL) approximate Riemann solver (Harten, 1983, Toro, 2001).

Other hydrological processes including precipitation, interception, and infiltration are simulated using methods similar to CASC2D (Julien, et al., 1995). In this study, the precipitation intensity is the bias-corrected precipitation at each cell. The interception loss is modeled by the concept of interception depth. If the precipitation is less than the interception depth, the rainfall excess rate is equal to zero for that time step. As soon as the interception depth is satisfied, the rainfall excess is generated, and accounted in the mass conservation equation. The Green-Ampt model is used for calculating the infiltration loss. By neglecting the ponding on the surface, the Green-Ampt model is written as:

$$
f=K_{s}\left(1+\frac{H_{f} M_{d}}{F}\right)
$$

where $f$ is the infiltration rate, $K_{s}$ is the saturated hydraulic conductivity, $H_{f}$ is the capillary pressure head at the wetting front, $M_{d}$ is the soil moisture deficit, $F$ is the total infiltrated depth. At each time step, the infiltrated loss is subtracted from rainfall intensity to obtain rainfall excess in Eq. (4). The flowchart for the model is shown in Fig. 10.

\subsection{Model Calibration}


The CHRE2D model has been verified by many experimental and field cases ( $\mathrm{Yu}$ and Duan 2014, 2016). In this study, the model was calibrated using a summer event to determine the modeling parameters, such as infiltration rate. The rainfall event started in July $15^{\text {th }}, 1999$, and lasted for 56 hours. The Cortaro gauge, located near the downstream outlet of the study reach, recorded a peak discharge of $387.94 \mathrm{~m}^{3} / \mathrm{s}$, the largest flow in 1999. The hourly gridded precipitation data with a resolution of $32 \mathrm{~km}$ was obtained from NLDAS (http://ldas.gsfc.nasa.gov/nldas/NLDAS2forcing.php). The channel transmission loss was treated similarly as the infiltration loss. Two infiltration rates are defined at each cell, one is for the overland flow, and the other is for the channel flow. If flow depth in a cell is greater than $0.1 \mathrm{~m}$, the flow is considered as channel flow, and the transmission loss is calculated based on the conductivity of channel flow. The soil texture types in the study area are loam (92.3\%) and silt (7.7\%). To simplify the computation, the model assigned loam soil type to each cell. Loam soil consists of $40 \%$ sand, $40 \%$ silt, and $20 \%$ clay, and the saturated hydraulic conductivity $\left(K_{s}\right)$ was calibrated as $0.0162 \mathrm{~m} / \mathrm{hr}$ for overland flow and $0.0324 \mathrm{~m} / \mathrm{hr}$ for channel flow, respectively. The capillary pressure head at the wetting front, $H_{f}$, is set as $11.01 \mathrm{~cm}$, and the calibrated one is $17 \mathrm{~cm}$. The soil moisture deficit, $M_{d}$, is 0.29 in the model. In Rawls et al., 1983 , the effective porosity of loam soil for 338 soil samples is 0.389 (Table 2, Page 67 in Rawls et al. 1983). The soil moisture deficit is the available porosity, calculated as the effective porosity minus the initial water content. The initial water content was assumed zero in the simulation. However, through model calibration, we found the optimal soil moisture deficit is 0.29 , which indicates the initial water content is approximately 0.1 . The Manning's roughness coefficient is 0.03 . 
The grid size is $100 \mathrm{~m}$ by $100 \mathrm{~m}$. The time step ranges from $1.0 \mathrm{~s}$, and it takes about 1.5 hours to run a 24-hour storm event. The model runs on a 12-core DELL server.

The infiltration rate is a function of three parameters: hydraulic conductivity, capillary pressure head, and soil moisture deficit. From the calibration, we found hydraulic conductivity is the most sensitive parameter. Three hydraulic conductivities for overland flow, $0.0144 \mathrm{~cm} / \mathrm{hr}, 0.0162 \mathrm{~cm} / \mathrm{hr}$ and $0.018 \mathrm{~cm} / \mathrm{hr}$, were used to analyze the sensitivity of modeling results. The hydraulic conductivity for channel flow is twice that for overland flow. The observed and simulated hydrographs using different hydraulic conductivities are shown in Figure 11. The results by using the hydraulic conductivity of $0.0162 \mathrm{~cm} / \mathrm{hr}$ best matched the observations. The model overestimated flow discharge using the hydraulic conductivity of $0.0144 \mathrm{~cm} / \mathrm{hr}$, while underestimated it using 0.018 $\mathrm{cm} / \mathrm{hr}$.

The simulated hydrograph matched the peak arriving time and the peak discharge observed at the Cortaro gauge when using the hydraulic conductivity of $0.0162 \mathrm{~cm} / \mathrm{hr}$. However, the measured low flow during the first several hours was not captured by the model because of the coarse mesh resolution and the insufficient soil moisture data before the event. Nevertheless, the model accurately predicted the peak discharge and the peak arriving time, which is essential for flood intensity and frequency analysis (Figure 12).

Furthermore, the model was applied to simulate 39 significant rainfall events occurred in 1991-2000. The durations for the simulated rainfall events in the period 19912000 are ranging from 6 to 54 hours with a medium duration of 14 hours. The largest 
annual peak discharge is about $778.7 \mathrm{~m}^{3} / \mathrm{s}$. The model over-estimated peak discharges for $180 \mathrm{~m}^{3} / \mathrm{s}<\mathrm{Q}<400 \mathrm{~m}^{3} / \mathrm{s}$, while underestimated smaller and larger flows beyond this range (Fig.13). In general, the simulated peak discharges matched well with the observed. The root-mean square error is $22.8 \mathrm{~m}^{3} / \mathrm{s}$. The normalized root-mean-square error (NRMSE) using the range of observed data is $3.02 \%$. The simulated results of three large flood events occurred in Winter (Feb 1998), Spring (March 1992), Fall (Nov. 2000) show the model captured the peak discharge, but has difficulty matching the rising and receding limbs (Fig.14). These results demonstrate the calibrated CHRE2D model is capable of capturing peak flows occurred in four seasons (Fig.14).

\section{Results}

The calibrated CHRE2D model was used to simulate surface flow routing over the SCRW for two future periods using the bias-corrected precipitation. Flood frequency curves were calculated according to USGS Bulletin 17-B guideline (Flynn et al., 2006) (Fig.15). The observed historical annual peak discharges from 1940 to 2013 were used for developing the current flood frequency curve. To incorporate the influences of future climate, the simulated annual peaks in two future periods, 2031-2040 and 2071-2079, together with the historical peak discharges from 1940 to 2013 were used to generate the future flood frequency curve. It's apparent the inclusion of annual peak flows from two future periods did not alter the frequency and discharge curves using Log-Pearson (LP) III distribution outlined in Bulletin 17B. The LP3 curve fitting cannot capture the largest peak flow within $90 \%$ confidence intervals. Therefore, the generalized extreme value (GEV) distribution was applied to fit both the data with and without the simulated peak flows in the two future periods (Fig. 16). The 90\% confidence intervals successfully 
enclosed the largest peak flow, but the duration and discharge curve is nearly the same regardless of the inclusion of future climate projected flows. The slight differences between two flood frequency curves for the return period greater than 100 years are calculated based on the GEV fit (Table 2). One can conclude that the discharge of 100year flood is increased by $64.5 \mathrm{~m}^{3} / \mathrm{s}$ when including the climate generated flow data. There is about a 5.3\% increase of the current 100-year flood discharge. The 200-year and 500-year flood discharge are increased about $92.7 \mathrm{~m}^{3} / \mathrm{s}$ and $144.5 \mathrm{~m}^{3} / \mathrm{s}$, respectively, which are about $6.2 \%$ and $7.6 \%$.

\section{Discussion}

This study used the climate model projected precipitation series for 1991-2000 to develop a set of bias-correction coefficient for two future periods: 2031-2040 and 2071-2079. However, the selected historical period doesn't include the largest flood event in Oct, 1983. The 1983 flood was a result of a widespread precipitation events lasting four days with a peak discharge of $1840.6 \mathrm{~m}^{3} / \mathrm{s}$, much larger than the selected calibration event in July 1999. Although precipitation in the SCR watershed primarily comes from the summer monsoon weather, significant infiltration and channel transmission loss as well as excessive groundwater pumpage in the upper SCR basin lead to smaller peak flows in the channel. Therefore, the surface flow routing model, CHRE2D, was first calibrated using a summer event, and then verified by 39 other events in the historical period (19912000). The calibrated model was used for simulating surface runoff in two future periods. Although the climate model projected slightly increased precipitation in two future periods, the increases of annual peak flows are negligible in the two future periods. 
Additionally, although the CHRE2D model is a state-of-the-art model capable of simulating both overland and channel flow simultaneously, it doesn't simulate the dynamic interaction between surface runoff and groundwater through infiltration, recharge, and transmission loss. A prior study (Shamir et al. 2015) found the minimal aquifer storage capability in the USCRW can result in rejected recharge. The upper SCR is subjected to increased transmission loss due to excessive development of groundwater resource. However, the current model assumed the soil conditions remained the same regardless of groundwater conditions. This simplification will lead to underestimating the peak flow in the channel as soil becomes saturated as flow reaches peak discharge. Consequently, it contributes to the results of minor increased flow discharge in the Cortaro gauge in the lower SCR. Nevertheless, the increases of 100-year, 200-year, and 500 -year discharges are less than $8 \%$, which may not be sustainable if taking the increase of groundwater pumping and soil infiltration into account. Shamir et al (2015) found that "projected climate impacts to flood recharge including peak flood flow, infer that future transmission losses will increase in the future, and thus result in lower peak flood flows along the upper reaches of the Santa Cruz River Valley”. The results from this study confirm the possibility of reduced peak flood flow in the SCR basin. However, this conclusion needs to be further verified by treating the soil properties as time-dependent variables, and incorporating pumped flow in the simulation.

\section{Conclusions}

This research applied a hydrodynamic model to route bias-corrected precipitation from the WRF regional climate model to quantify possible changes in flood magnitude 
and frequency in the upper SCR basin. By using the precipitation data for the historical (1991-2000) and future (2031-2040, 2071-2079) periods as input to the CHRE2D model, flow discharges in the channel were obtained at the Cortaro gauge. The simulated flow discharges in the historical period closely matched with the observed data. The simulated annual peak flows in two future periods were added to the observed flow database for flood magnitude and frequency analysis.

Flood discharges for 100-year, 200-year, and 500-year periods were slightly increased when incorporating the simulated flood flows in two future periods. However, the increases of annual peak flow by the inclusion of climate model projected date are within the $90 \%$ confidence interval limits. The results imply that the flood magnitude and frequency curve will remain nearly unchanged for the study site.

\section{Acknowledgement}

This research is funded by NSF Water Climate Sustainability Program under award number EAR-1038938.

\section{Reference}

Booij, M., 2005. Impact of climate change on river flooding assessed with different spatial model resolutions. Journal of hydrology, 303(1): 176-198.

Cea, L., and M. E. Vazquez-Cendon, 2012. Unstructured finite volume discretisation of bed friction and convective flux in solute transport models linked to the shallow water equations, J Comput Phys, 231(8), 3317-3339.

Chen, F., Dudhia, J., 2001. Coupling an advanced land surface-hydrology model with the Penn State-NCAR MM5 modeling system. Part I: Model implementation and sensitivity. Monthly Weather Review, 129(4): 569-585. 
Chen, Z., Grasby, S.E., 2014. Reconstructing river discharge trends from climate variables and prediction of future trends. Journal of Hydrology, 511: 267-278.

Chou, M.-D., Suarez, M.J., 1994. An efficient thermal infrared radiation parameterization for use in general circulation models. NASA Tech. Memo, 104606(3): 85.

Dominguez, F. and J. Canon and J. Valdes, 2009. IPCC-AR4 Climate Simulations For The Southwestern US: The Importance Of Future ENSO Projections. Climatic Change DOI: 10.1007/s10584-009-9672-5.

Dominguez, F., Rivera, E., Lettenmaier, D., Castro, C., 2012. Changes in winter precipitation extremes for the western United States under a warmer climate as simulated by regional climate models. Geophysical Research Letters, 39(5).

Driscoll E. D., Palhegyi, G.E, Strecker, E.W., Shelley, P.E., 1989. Analysis of Storm Event Characteritics for Selected rainfall Gages Throughout the United States. Technical Report, US Environmental Protection Agency, 48 pages.

Flato, G., J. Marotzke, B. Abiodun, P. Braconnot, S.C. Chou, W. Collins, P. Cox, F. Driouech, S. Emori, V. Eyring, C. Forest, P. Gleckler, E. Guilyardi, C. Jakob, V. Kattsov, C. Reason and M. Rummukainen, 2013: Evaluation of Climate Models. In: Climate Change 2013: The Physical Science Basis. Contribution of Working Group I to the Fifth Assessment Report of the Intergovernmental Panel on Climate Change [Stocker, T.F., D. Qin, G.-K. Plattner, M. Tignor, S.K. Allen, J. Boschung, A. Nauels, Y. Xia, V. Bex and P.M. Midgley (eds.)]. Cambridge University Press, Cambridge, United Kingdom and New York, NY, USA.

Flynn, K.M., Kirby, W.H., Hummel, P.R., 2006. User's manual for program PeakFQ, annual floodfrequency analysis using bulletin 17B guidelines. US Department of the Interior, US Geological Survey.

Fowler, H., Kilsby, C., 2007. Using regional climate model data to simulate historical and future river flows in northwest England. Climatic Change, 80(3-4): 337-367.

Fraccarollo, L., Toro, E.F., 1995. Experimental and numerical assessment of the shallow water model for two-dimensional dam-break type problems. Journal of hydraulic research, 33(6): 843-864.

Garcia-Navarro, P., Hubbard, M., Priestley, A., 1995. Genuinely multidimensional upwinding for the 2D shallow water equations. Journal of Computational Physics, 121(1): 79-93.

Geil, K and Y. Serra and X. Zeng, 2013. Assessment of CMIP5 Model Simulations of the North American Monsoon System, J. Climate V. 26. 
Gordon, C., Cooper, C., Senior, C. A., Banks, H., Gregory, J. M., Johns, T. C., Mitchell, J.F.B., Wood, R.A., 2000. The simulation of SST, sea ice extents and ocean heat transports in a version of the Hadley Centre coupled model without flux adjustments. Climate Dynamics, 16(23): $147-168$.

Harten, A., 1983. High-Resolution Schemes for Hyperbolic Conservation-Laws. J Comput Phys, 49(3): 357-393.

Hanel, M., Buishand, T.A., 2010. On the value of hourly precipitation extremes in regional climate model simulations. Journal of hydrology, 393(3): 265-273.

Hong, S.-Y., Dudhia, J., Chen, S.-H., 2004. A revised approach to ice microphysical processes for the bulk parameterization of clouds and precipitation. Monthly Weather Review, 132(1): 103-120.

International Federation of Red Cross and Red Crescent Societies (IFRCRCS), and Centre for Research on the Epidemiology of Disasters. 2012. World disasters report. Roger Zetter editor, ISBN 978-92-9139-187-5. http://www.ifrc.org/Global/Documents/Secretariat/2012_WDR_Full_Report.pdf

Janjic, Z.I., 1990. The step-mountain coordinate: Physical package. Monthly Weather Review, 118(7): 1429-1443.

Janjic, Z., 1996. The surface layer parameterization in the NCEP Eta Model. WORLD METEOROLOGICAL ORGANIZATION-PUBLICATIONS-WMO TD: 4.16-4.17.

Janjić, Z.I., 2002. Nonsingular implementation of the Mellor-Yamada level 2.5 scheme in the NCEP Meso model. NCEP office note, 437: 61.

Julien, P. Y., B. Saghafian, and F. L. Ogden, 1995. Raster-Based Hydrologic Modeling of SpatiallyVaried Surface Runoff, Water Resour Bull, 31(3), 523-536.

Kain, J.S., Fritsch, J. M., 1993. Convective parameterization for mesoscale models: The KainFritsch scheme. The representation of cumulus convection in numerical models, Meteor. Monogr, No. 24, Amer. Meteor. Soc., 165-170.

Kay, A.L., Jones, R.G., Reynard, N.S., 2006a. RCM rainfall for UK flood frequency estimation. II. Climate change results. Journal of hydrology, 318(1): 163-172.

Kay, A.L., Reynard, N.S., Jones, R.G., 2006b. RCM rainfall for UK flood frequency estimation. I. Method and validation. Journal of hydrology, 318(1): 151-162. 
Kim, J., A. Warnock, V. Y. Ivanov, and N. D. Katopodes, 2012. Coupled modeling of hydrologic and hydrodynamic processes including overland and channel flow, Adv Water Resour, 37, 104-126.

Leonard, M., Metcalfe, A., Lambert, M., 2008. Frequency analysis of rainfall and streamflow extremes accounting for seasonal and climatic partitions. Journal of hydrology, 348(1): 135-147.

LeVeque, R.J., 2002. Finite volume methods for hyperbolic problems. Cambridge texts in applied mathematics. Cambridge University Press, Cambridge ; New York, xix, 558 p.

Li, F., Zhang, Y., Xu, Z., Teng, J., Liu, C., Liu, W., Mpelasoka, F., 2013. The impact of climate change on runoff in the southeastern Tibetan Plateau. Journal of Hydrology, 505: 188201.

Mearns, L. O., W. Gutowski, R. Jones, R. Leung, S. McGinnis, A. Nunes, and Y. Qian, 2009. A Regional Climate Change Assessment Program for North America, Eos Trans. AGU, 90(36), 311-311, doi:10.1029/2009EO360002.

Merritt, W.S., Alila, Y., Barton, M., Taylor, B., Cohen, S., Neilsen, D., 2006. Hydrologic response to scenarios of climate change in sub watersheds of the Okanagan basin, British Columbia. Journal of Hydrology, 326(1): 79-108.

Miguez-Macho, G., Stenchikov, G.L., Robock, A., 2005. Regional climate simulations over North America: interaction of local processes with improved large-scale flow J. Clim., Vol. $18,1227-1246$

Mirza, M.M.Q., Warrick, R., Ericksen, N., 2003. The implications of climate change on floods of the Ganges, Brahmaputra and Meghna rivers in Bangladesh. Climatic Change, 57(3): 287-318.

Mlawer, E.J., Taubman, S.J., Brown, P.D., lacono, M.J., Clough, S.A., 1997. Radiative transfer for inhomogeneous atmospheres: RRTM, a validated correlated - $k$ model for the longwave. Journal of Geophysical Research: Atmospheres (1984 - 2012), 102(D14): 16663-16682.

Piani, C. et al., 2010. Statistical bias correction of global simulated daily precipitation and temperature for the application of hydrological models. Journal of Hydrology, 395(3): 199-215.

Pope, V., Gallani, M., Rowntree, P., Stratton, R., 2000. The impact of new physical parametrizations in the Hadley Centre climate model: HadAM3. Climate Dynamics, 16(23): 123-146. 
Ponce, V.M., 1989. Engineering hydrology : principles and practices. Prentice Hall, Englewood Cliffs, N.J., xv, 640 p.

Qu, Y., Duffy, C.J., 2007. A semidiscrete finite volume formulation for multiprocess watershed simulation. Water Resources Research, 43(8).

Raff, D., Pruitt, T., Brekke, L., 2009. A framework for assessing flood frequency based on climate projection information. Hydrology \& Earth System Sciences, 13(11).

Rawls, W.J., Brakensiek, D.L., Miller, N., 1983. Green-Ampt infiltration parameters from soils data. Journal of hydraulic engineering, 109(1): 62-70.

Singh, V., 2002. Is hydrology kinematic? Hydrological processes, 16(3): 667-716.

Schmidli, J., Frei, C., 2005. Trends of heavy precipitation and wet and dry spells in Switzerland during the 20th century. International Journal of Climatology, 25(6): 753-771.

Shamir, E., Meko, D.M., Graham, N.E., Georgakakos, K.P., 2007. Hydrologic Model Framework for Water Resources Planning in the Santa Cruz River, Southern Arizona1. JAWRA Journal of the American Water Resources Association, 43(5): 1155-1170.

Shamir, Eylon, Sharon B. Megdal, Carlos Carrillo, Christopher L. Castro, Hsin-I Chang, Karletta Chief, Frank E. Corkhill, Susanna Eden, Konstantine P. Georgakakos, Keith M. Nelson, Jacob Prietto, 2015. Climate Change and water resources management in the Upper Santa Cruz River, Arizona. Journal of Hydrology 521(2015) 18-33.

Skamarock, W.C. , Klemp, J.B., Dudhia, J., Gill, D.O., Barker, D.M., Wang, W., Powers, J. G., 2005. A description of the advanced research WRF version 2, NCAR Tech Note.

Toro, E. F. , 2001. Shock-capturing methods for free-surface shallow flows, xv, 309 p. pp., John Wiley, Chichester ; New York.

Toro, E.F., 2009. Riemann solvers and numerical methods for fluid dynamics : a practical introduction. Springer, Dordrecht ; New York, xxiv, 724 p. pp.

Vivoni, E., Entekhabi, D., Bras, R., Ivanov, V., 2007. Controls on runoff generation and scaledependence in a distributed hydrologic model. Hydrology \& Earth System Sciences, 11(5).

Wi, S., Dominguez, F., Durcik, M., Valdes, J.B., Diaz, H.F., Castro, C.L., 2012. Climate change projection of snowfall in the Colorado River Basin using dynamical downscaling. Water Resources Research, 48(5).

$\mathrm{Wu}, \mathrm{H}$. et al., 2012. Projected climate change impacts on the hydrology and temperature of Pacific Northwest rivers. Water Resources Research, 48(11). 
Wood, A.W., Maurer, E.P., Kumar, A., Lettenmaier, D.P., 2002. Long - range experimental hydrologic forecasting for the eastern United States. Journal of Geophysical Research: Atmospheres (1984-2012), 107(D20): ACL 6-1-ACL 6-15.

Wood, M.L., House, P.K., Pearthree, P.A., 1999. Historical geomorphology and hydrology of the Santa Cruz River. Arizona Geological Survey, page 5-8.

Yang, D., Kane, D., Zhang, Z., Legates, D., Goodison, B., 2005. Bias corrections of long - term (1973 - 2004) daily precipitation data over the northern regions. Geophysical Research Letters, 32(19).

Yu, C., Duan, J. G., 2012. Two-dimensional depth-averaged unsteady turbulent flow model over obstacles", Journal of Hydraulic Research, 50:6, 599-611.

Yu, C., Duan, J. G., 2014. Two-dimensional hydrodynamic model for surface-flow routing. Journal of Hydraulic Engineering. DOI:10.1061/(ASCE).HY.1943-7900.0000913.

Yu, C., Duan, J. G., 2016. "Simulation of surface runoff using hydrodynamic model", Journal of Hydrologic Engineering, doi:10.1061/(ASCE)HE.1943-5584.0001497.

Zhai, P., Zhang, X., Wan, H., Pan, X., 2005. Trends in total precipitation and frequency of daily precipitation extremes over China. Journal of climate, 18(7).

Zhao, D., Shen, H., Tabios III, G., Lai, J., Tan, W., 1994. Finite-volume two-dimensional unsteadyflow model for river basins. Journal of Hydraulic Engineering, 120(7): 863-883. 
Table 1. Number of WRF simulated and observed storm events during 1991-2000

\begin{tabular}{|c|c|c|c|c|c|c|c|c|}
\hline \multirow{2}{*}{$\begin{array}{c}\text { Cell } \\
\text { Number }\end{array}$} & \multicolumn{2}{|c|}{ Spring } & \multicolumn{2}{|c|}{ Summer } & \multicolumn{2}{|c|}{ Fall } & \multicolumn{2}{|c|}{ Winter } \\
\hline & WRF* & Obs $* *$ & WRF & Obs & WRF & Obs & WRF & Obs \\
\hline 1 & 180 & 101 & 613 & 551 & 47 & 46 & 220 & 311 \\
\hline 2 & 180 & 103 & 640 & 561 & 46 & 46 & 221 & 295 \\
\hline 3 & 187 & 106 & 643 & 568 & 42 & 49 & 223 & 303 \\
\hline 4 & 197 & 115 & 648 & 623 & 45 & 47 & 225 & 305 \\
\hline 5 & 206 & 125 & 652 & 612 & 56 & 47 & 239 & 301 \\
\hline 6 & 181 & 102 & 611 & 581 & 46 & 53 & 220 & 317 \\
\hline 7 & 193 & 100 & 617 & 569 & 38 & 49 & 226 & 292 \\
\hline 8 & 209 & 121 & 623 & 572 & 44 & 62 & 246 & 318 \\
\hline 9 & 215 & 124 & 596 & 575 & 55 & 53 & 242 & 294 \\
\hline 10 & 212 & 128 & 616 & 595 & 52 & 51 & 234 & 294 \\
\hline 11 & 179 & 101 & 577 & 564 & 41 & 54 & 214 & 315 \\
\hline 12 & 192 & 99 & 590 & 554 & 34 & 52 & 237 & 302 \\
\hline 13 & 219 & 122 & 613 & 575 & 51 & 60 & 243 & 316 \\
\hline 14 & 223 & 136 & 593 & 596 & 64 & 60 & 250 & 331 \\
\hline 15 & 214 & 124 & 594 & 574 & 57 & 45 & 251 & 304 \\
\hline 16 & 190 & 101 & 572 & 578 & 43 & 52 & 224 & 324 \\
\hline 17 & 180 & 101 & 566 & 548 & 36 & 53 & 232 & 295 \\
\hline 18 & 210 & 122 & 594 & 547 & 43 & 57 & 243 & 314 \\
\hline 19 & 218 & 132 & 591 & 573 & 52 & 58 & 241 & 328 \\
\hline 20 & 202 & 126 & 598 & 563 & 51 & 51 & 254 & 320 \\
\hline 21 & 195 & 106 & 564 & 546 & 41 & 52 & 235 & 307 \\
\hline 22 & 188 & 105 & 540 & 518 & 36 & 51 & 243 & 289 \\
\hline 23 & 181 & 119 & 521 & 506 & 33 & 62 & 231 & 292 \\
\hline 24 & 178 & 116 & 545 & 534 & 41 & 54 & 232 & 293 \\
\hline 25 & 190 & 121 & 557 & 526 & 45 & 58 & 229 & 298 \\
\hline 26 & 175 & 95 & 537 & 485 & 29 & 48 & 226 & 267 \\
\hline 27 & 175 & 93 & 526 & 467 & 32 & 49 & 225 & 255 \\
\hline 28 & 174 & 108 & 511 & 449 & 32 & 53 & 233 & 257 \\
\hline 29 & 170 & 117 & 533 & 453 & 32 & 52 & 218 & 291 \\
\hline 30 & 185 & 116 & 553 & 438 & 38 & 52 & 232 & 288 \\
\hline 31 & 149 & 91 & 448 & 450 & 26 & 42 & 214 & 264 \\
\hline 32 & 158 & 91 & 477 & 454 & 26 & 48 & 209 & 262 \\
\hline 33 & 165 & 95 & 476 & 437 & 29 & 43 & 216 & 263 \\
\hline 34 & 165 & 107 & 495 & 457 & 30 & 54 & 226 & 286 \\
\hline 35 & 195 & 118 & 555 & 442 & 42 & 51 & 241 & 297 \\
\hline 36 & 152 & 90 & 473 & 433 & 28 & 42 & 205 & 286 \\
\hline
\end{tabular}




\begin{tabular}{|l|c|c|c|c|c|c|c|c|}
37 & 159 & 96 & 478 & 431 & 20 & 43 & 216 & 282 \\
\hline 38 & 189 & 95 & 522 & 459 & 31 & 50 & 231 & 320 \\
\hline 39 & 221 & 106 & 568 & 483 & 38 & 51 & 256 & 329 \\
\hline 40 & 236 & 119 & 576 & 488 & 48 & 57 & 258 & 345 \\
\hline 41 & 150 & 92 & 467 & 453 & 20 & 44 & 213 & 279 \\
\hline 42 & 154 & 107 & 490 & 477 & 23 & 46 & 219 & 308 \\
\hline 43 & 182 & 110 & 522 & 477 & 37 & 47 & 226 & 316 \\
\hline 44 & 222 & 128 & 558 & 525 & 54 & 53 & 258 & 382 \\
\hline 45 & 225 & 126 & 574 & 499 & 66 & 52 & 265 & 362 \\
\hline
\end{tabular}

Note: WRF ${ }^{*}$ - number of events generated from WRF simulation

Obs** - number of observed events

Table 2. Increase of annual flow discharge using generalized extreme value

\begin{tabular}{|c|c|c|c|c|}
\hline $\begin{array}{c}\text { Return } \\
\text { Period (year) }\end{array}$ & $\begin{array}{c}\text { Discharge by } \\
\text { Adding Climate } \\
\text { Data }\left(\mathrm{m}^{3} / \mathrm{s}\right)\end{array}$ & $\begin{array}{c}\text { Discharge with } \\
\text { only Historical } \\
\text { Data }\left(\mathrm{m}^{3} / \mathrm{s}\right)\end{array}$ & Increase $\left(\mathrm{m}^{3} / \mathrm{s}\right)$ & Percentage \\
\hline 500 & 2048.20 & 1903.74 & 144.46 & $7.59 \%$ \\
\hline 200 & 1579.09 & 1486.35 & 92.74 & $6.24 \%$ \\
\hline 100 & 1284.99 & 1220.47 & 64.53 & $5.29 \%$ \\
\hline 50 & 1034.29 & 990.70 & 43.59 & $4.40 \%$ \\
\hline 25 & 819.96 & 791.55 & 28.41 & $3.59 \%$ \\
\hline
\end{tabular}




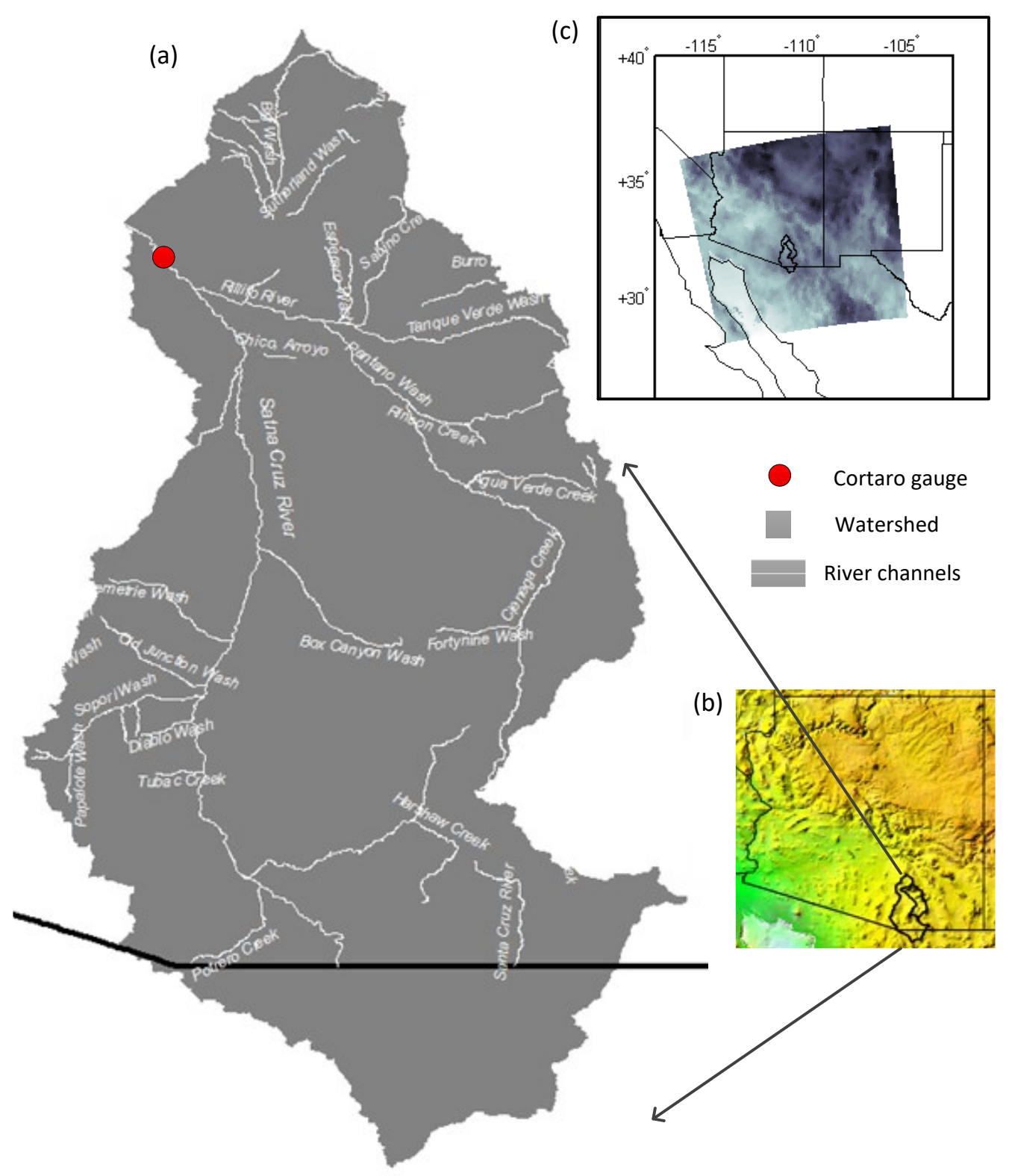

Figure 1 Map of the Upper Santa Cruz River Watershed. (a) USCRW with River network information; (b) location of USCRW; (c) RCM climate model simulation region. 


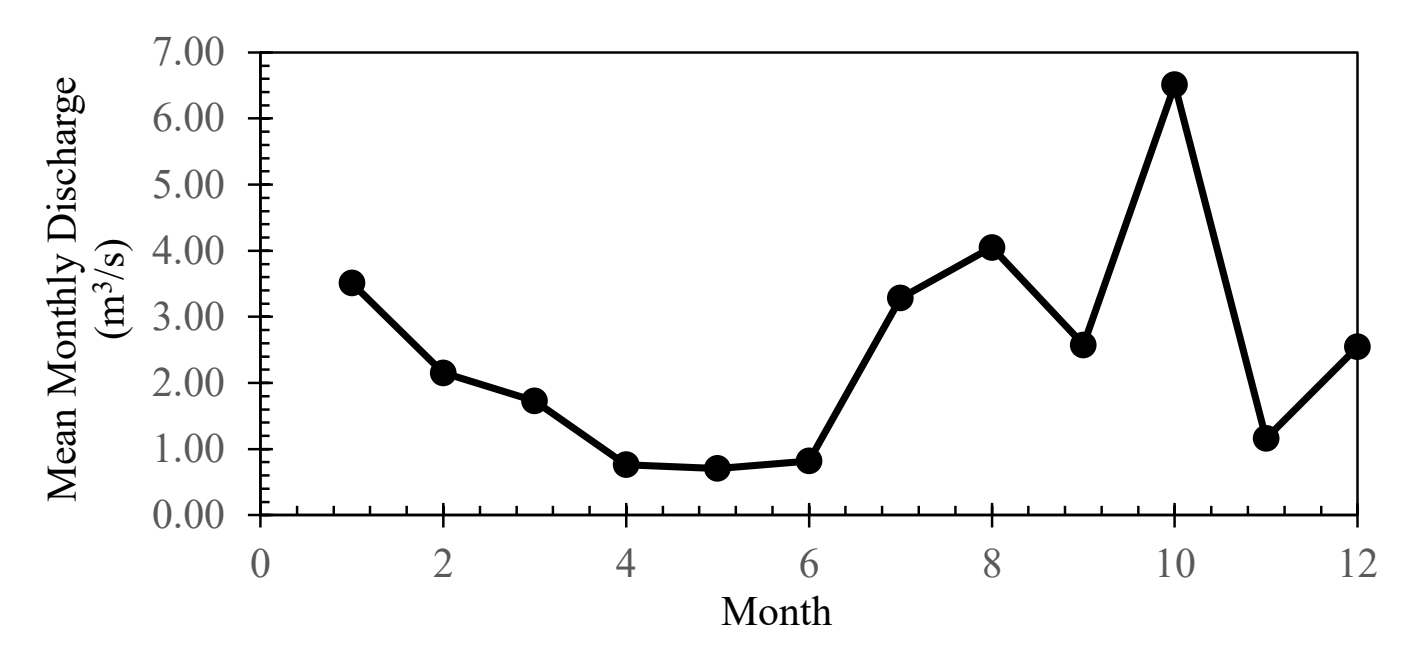

Figure 2 Monthly average streamflow at Cortaro gauge from 1940 to 2013

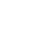

Figure 2 Monthly average streamflow at Cortaro gauge from 1940 to 2013

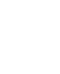

(1)




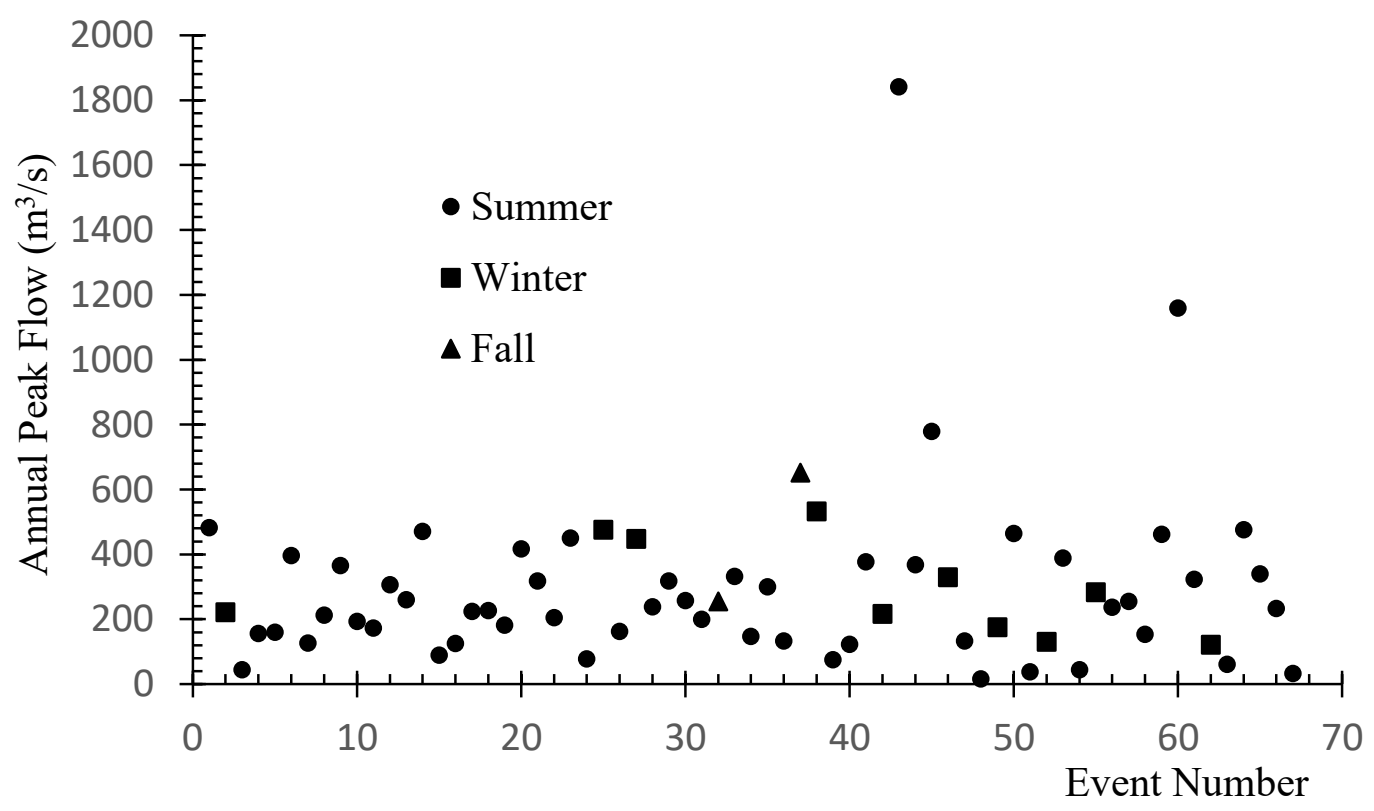

Figure 3 Annual peak flow at Cortaro gauge (circle, square and triangular makers indicate the flow happened in the summer, fall and winter seasons of data year, respectively) 


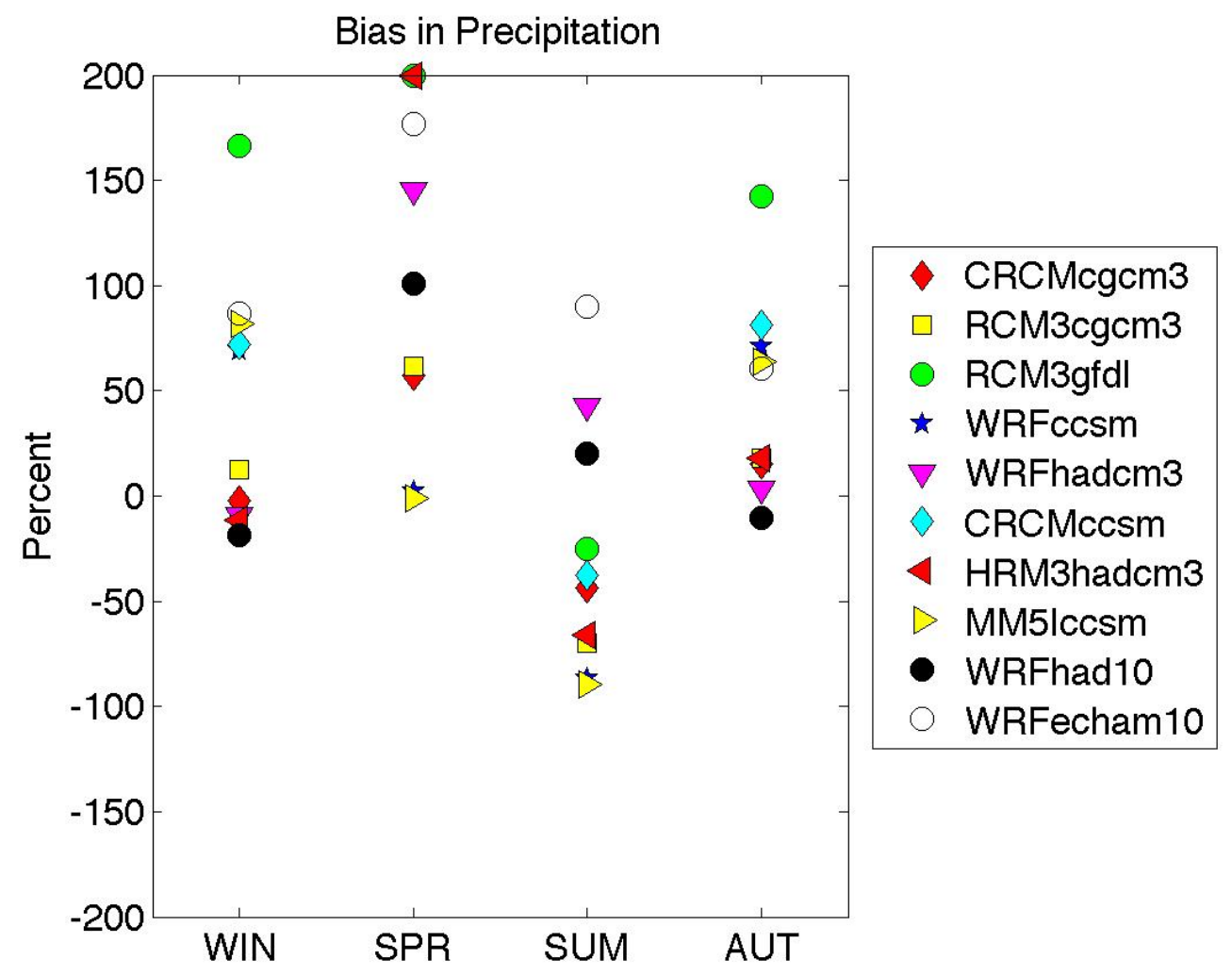

Figure 4 Bias in WRFhad10 simulations (black dots) and other NARCCAP simulations when compared to NARR data, used here as a proxy for observations 


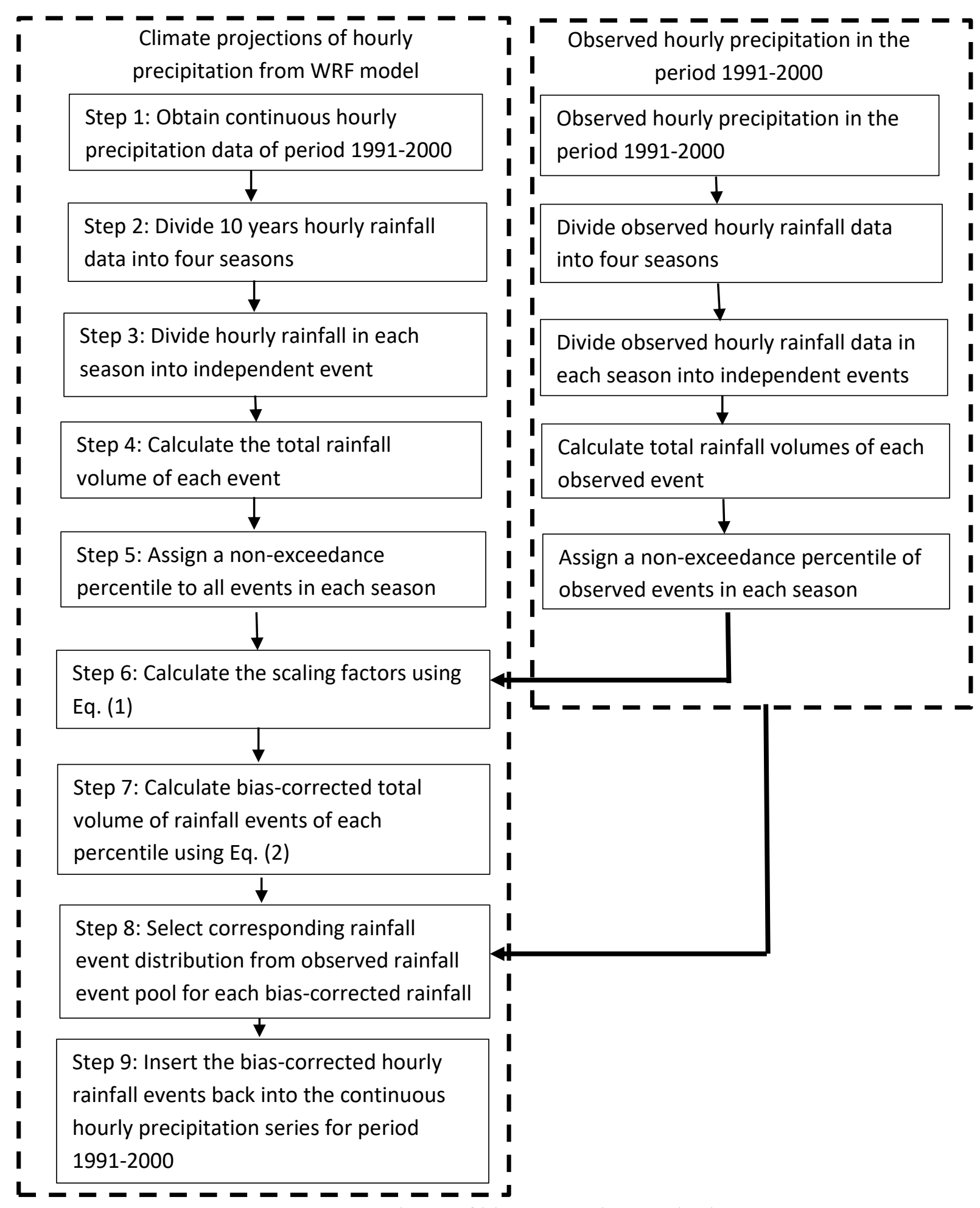

Figure 5 Procedures of bias-correction method 


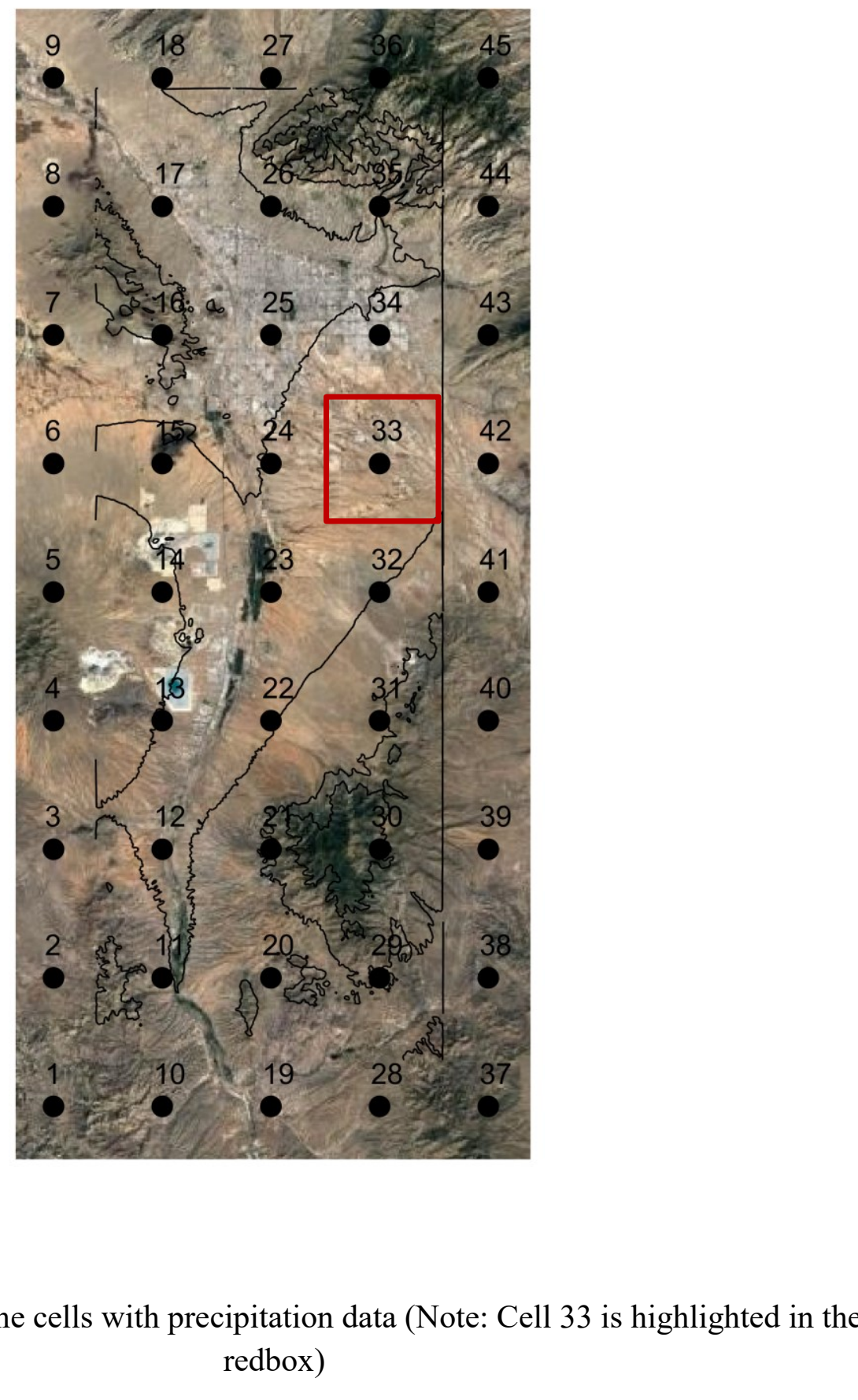

Figure 6 Locations of the cells with precipitation data (Note: Cell 33 is highlighted in the redbox)

Figure 6 Locations of the cells with precipitation data (Note: Cell 33 is hightighted in the

.

133 is highlighted in the

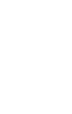



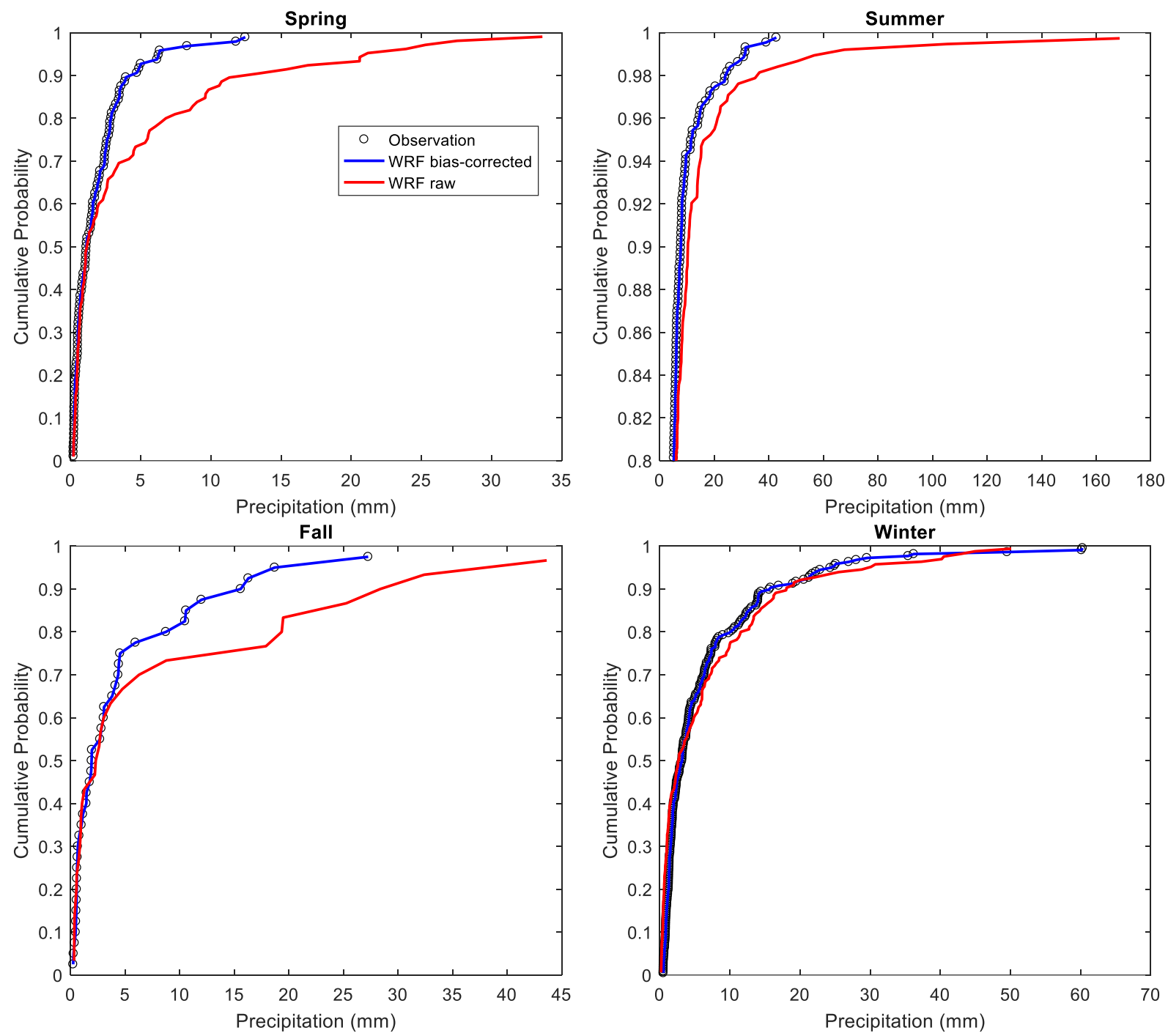

Figure 7 Cumulative distribution functions of total precipitation volume in each event for four seasons during the period $1991-2000$ at cell 33 

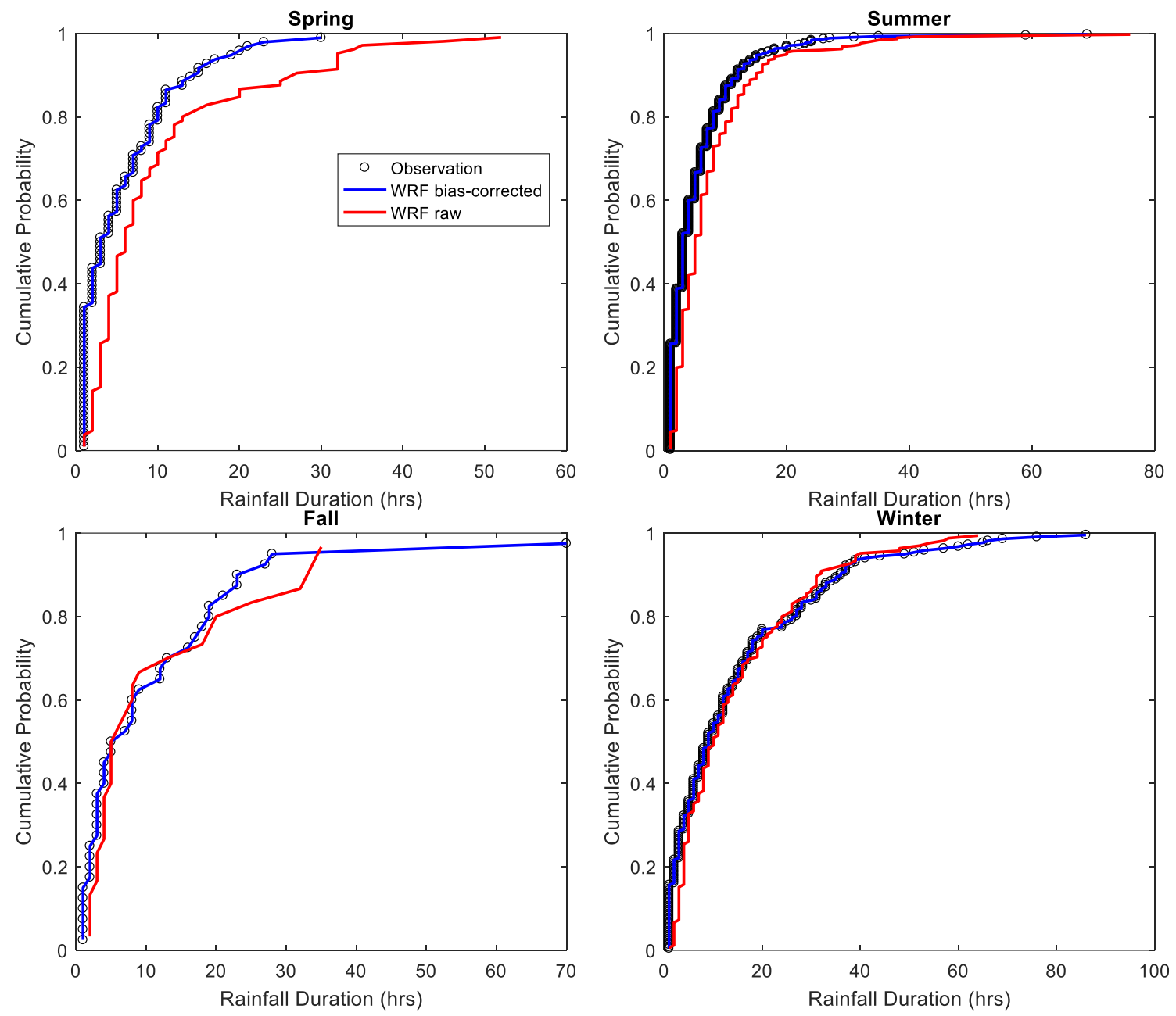

Figure 8 Cumulative distribution functions of rainfall duration for four seasons during the period 1991-2000 at cell 33 

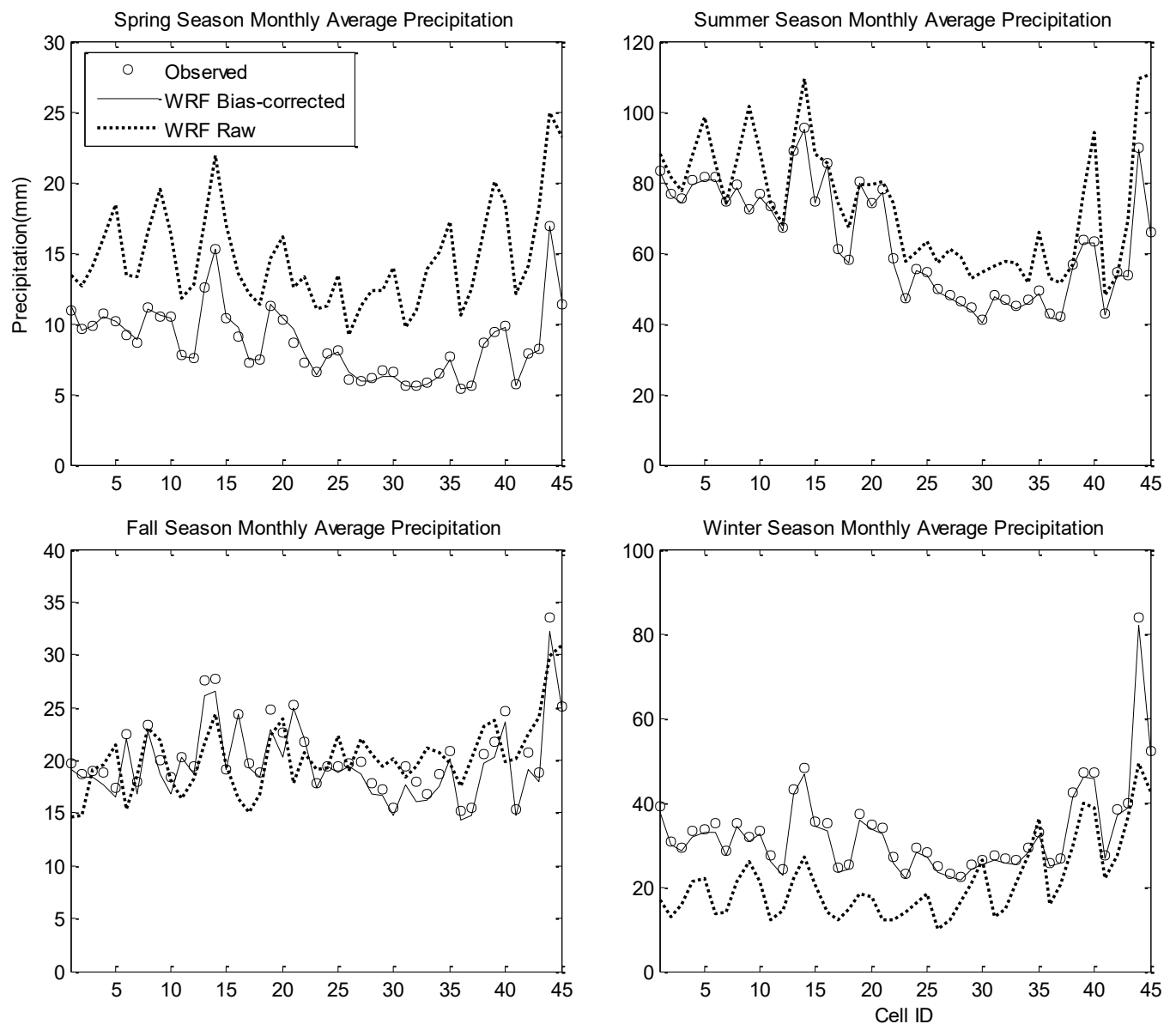

Figure 9 Seasonal-averaged monthly precipitations in each season for period 1991-2000 


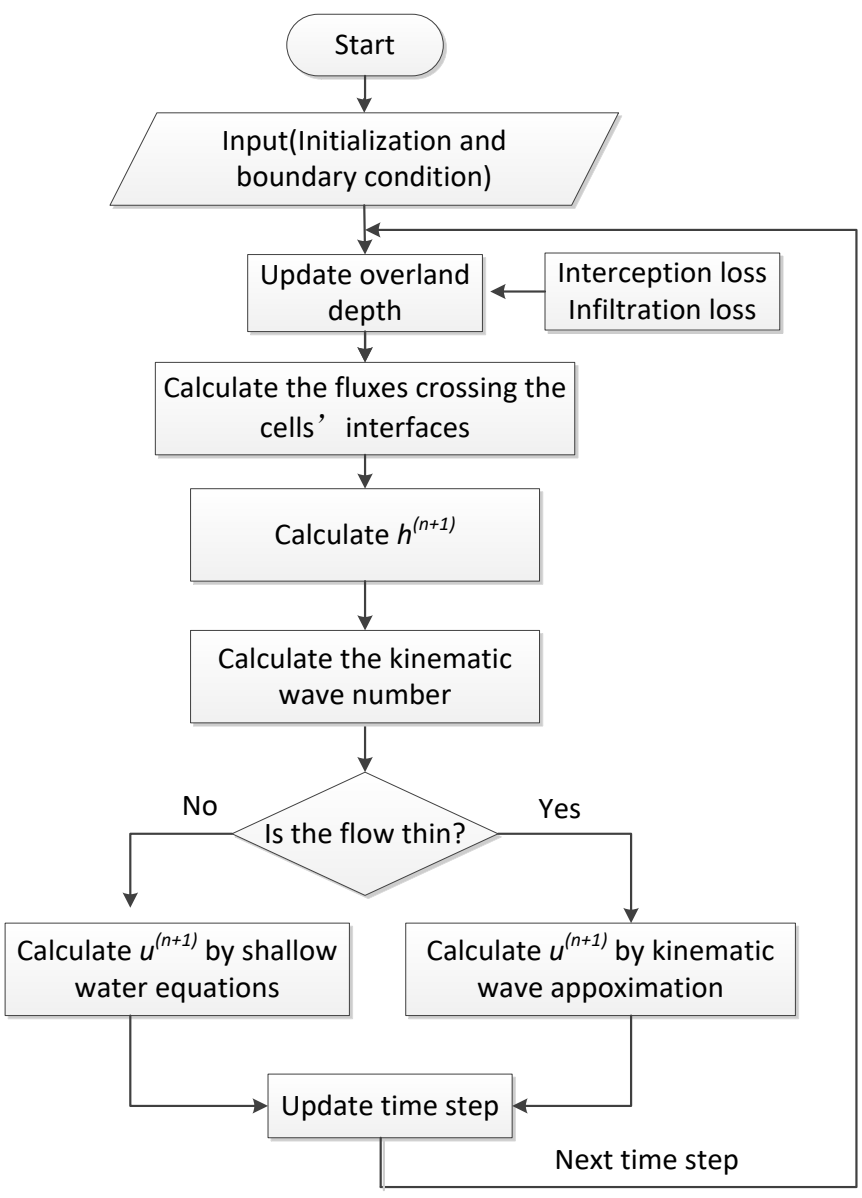

Figure 10 Flowchart of CHRE2D model 


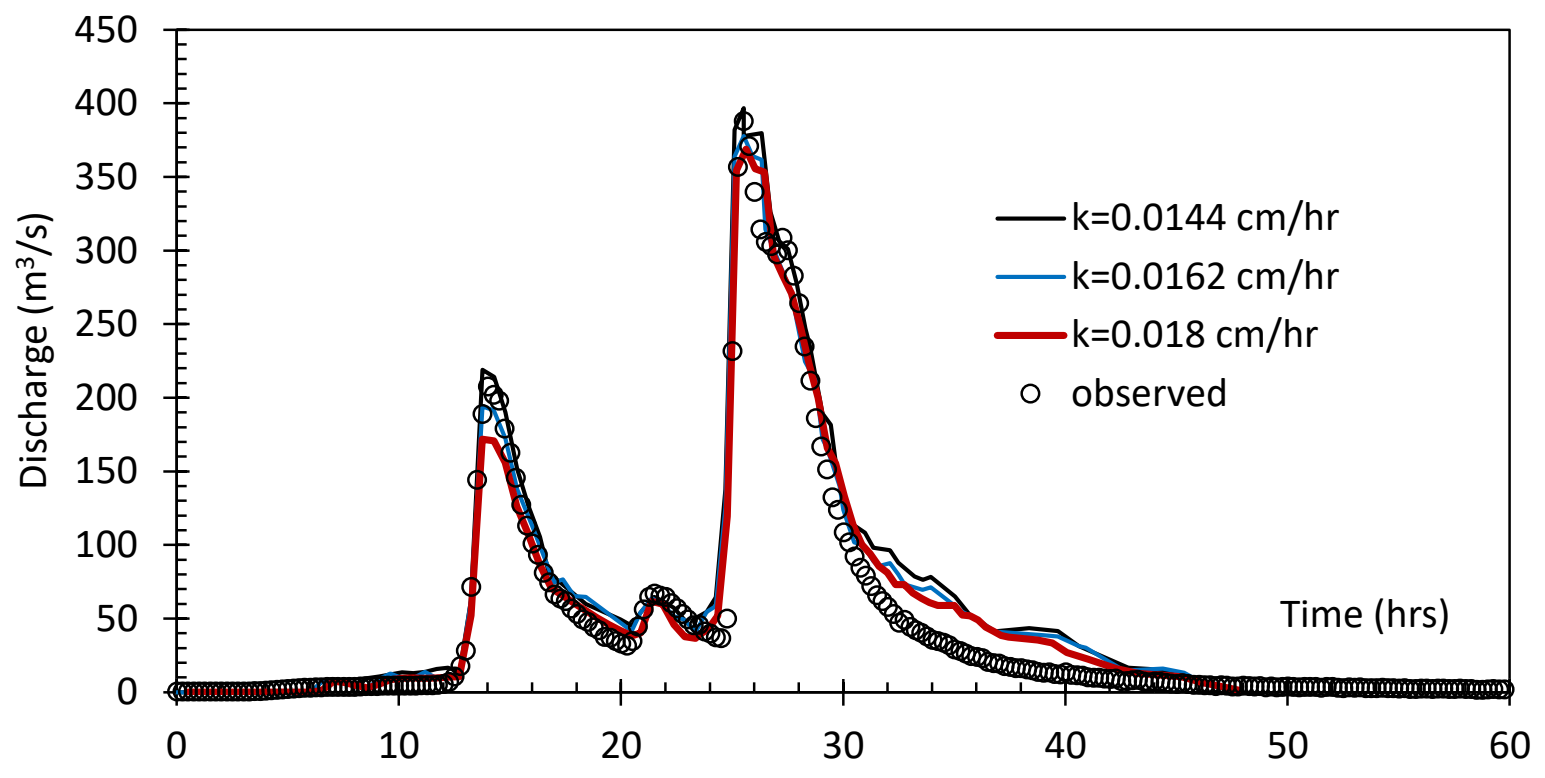

Figure 11 Measured and simulated hydrograph at Cortaro gauge of July $15^{\text {th }}, 1999$ 


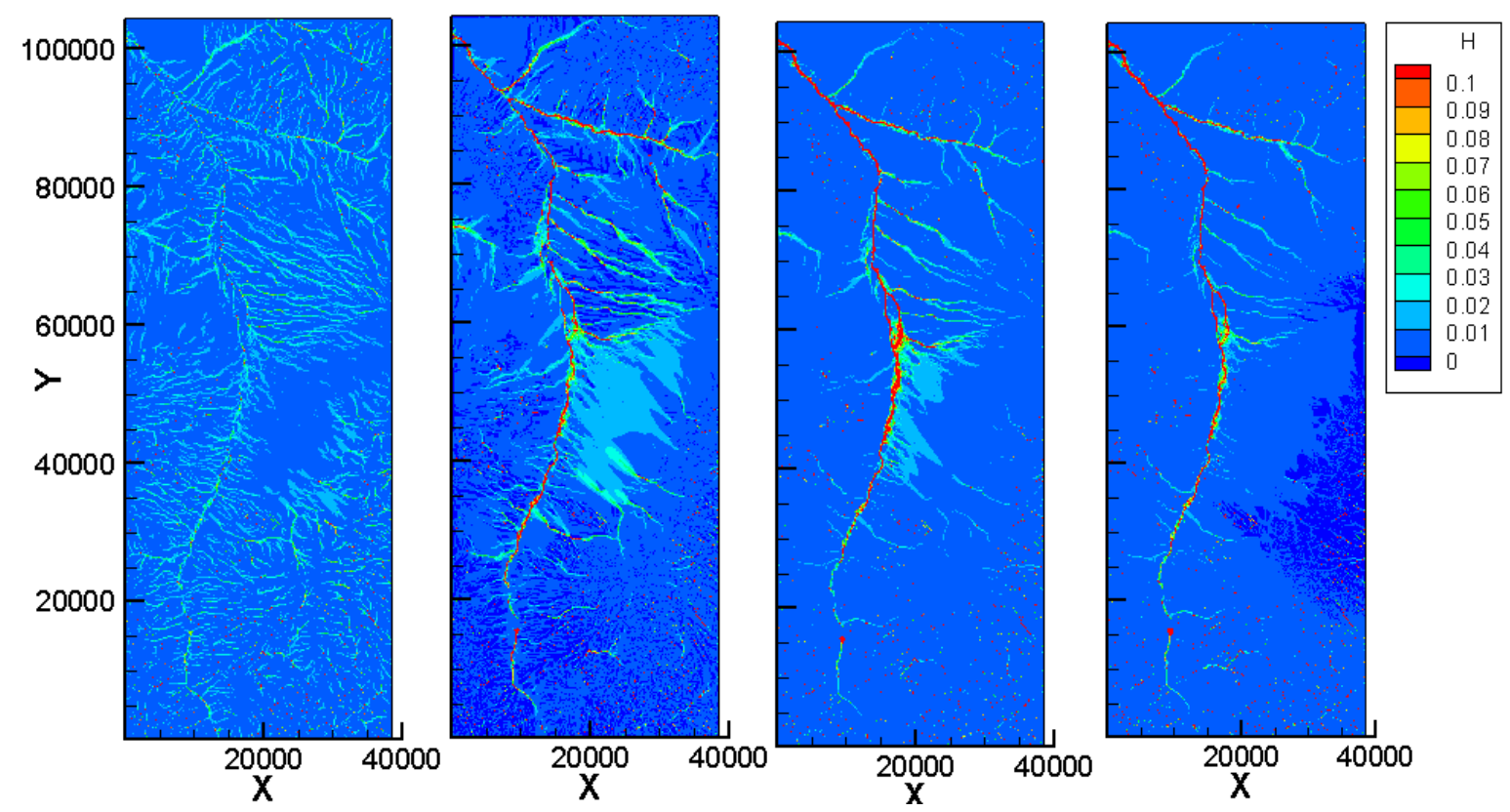

Figure 12 Water depth at different time $(t=6,8,12,22$ hours $)$ for July $15^{\text {th }}, 1999$ flood event. 


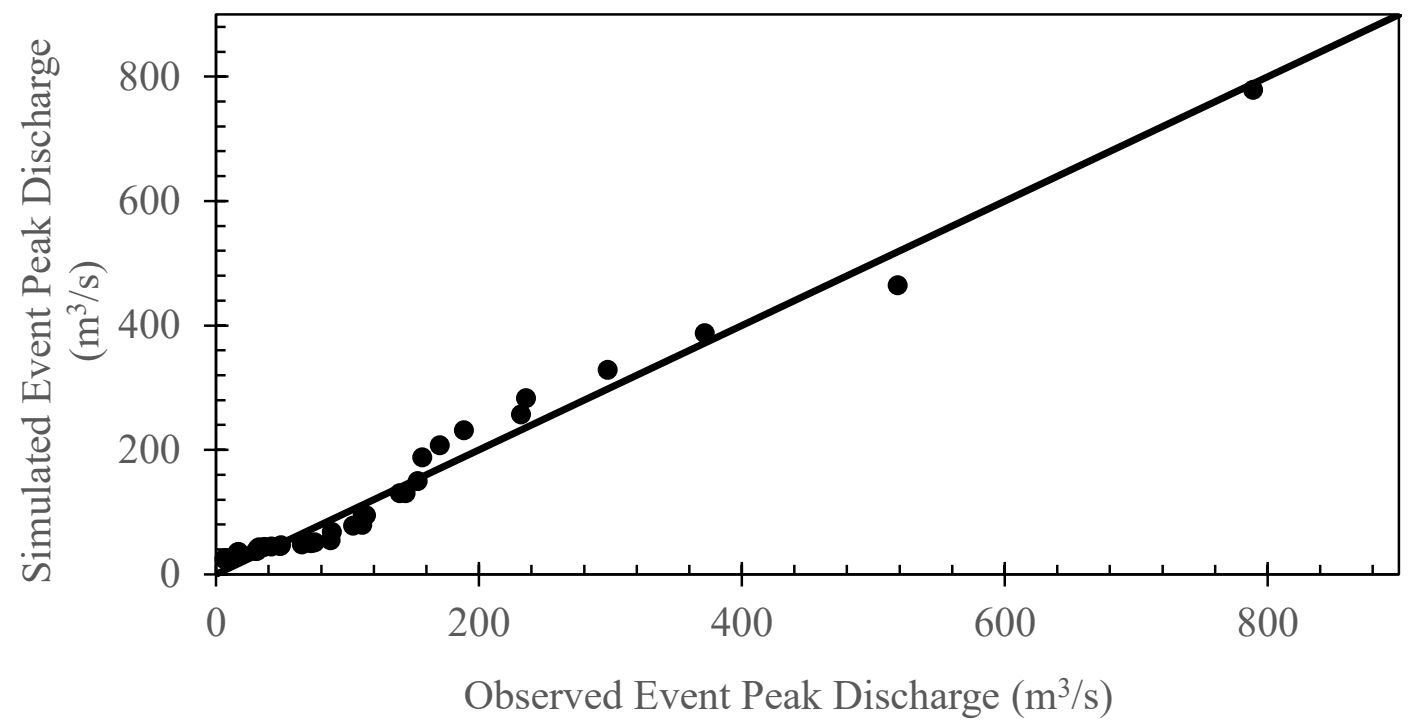

Figure 13 Comparison of simulated and observed event peak discharges during 19912000 


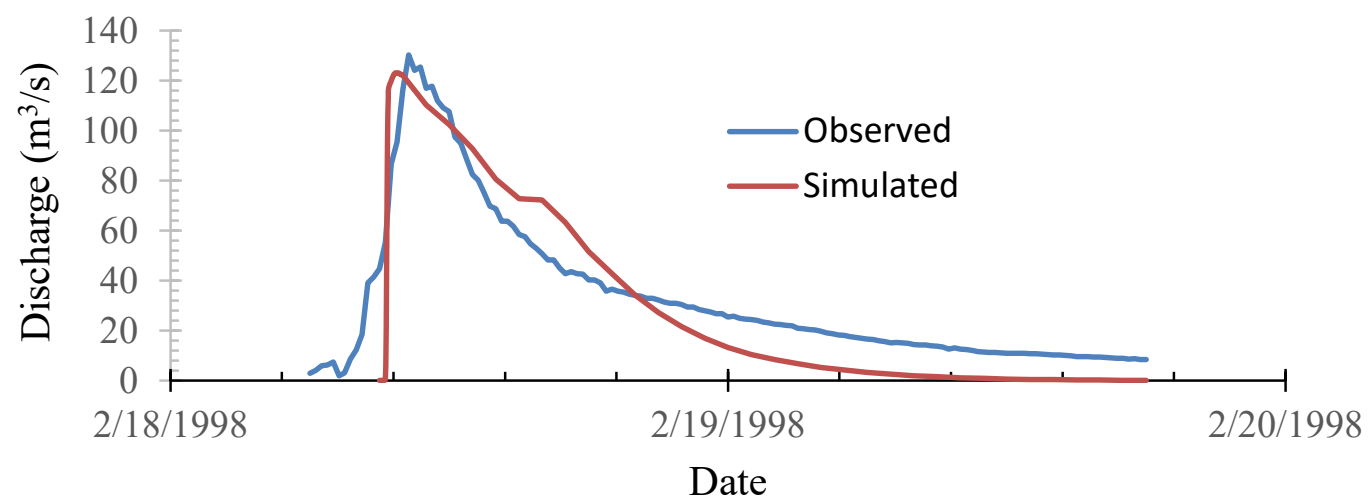

(a) Winter

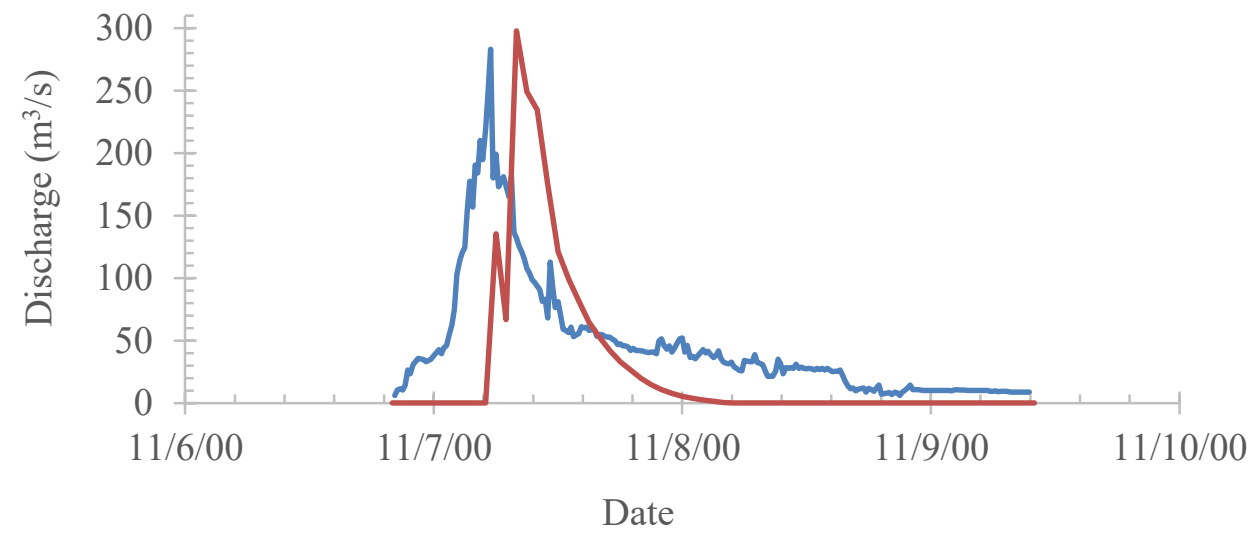

(b) Fall

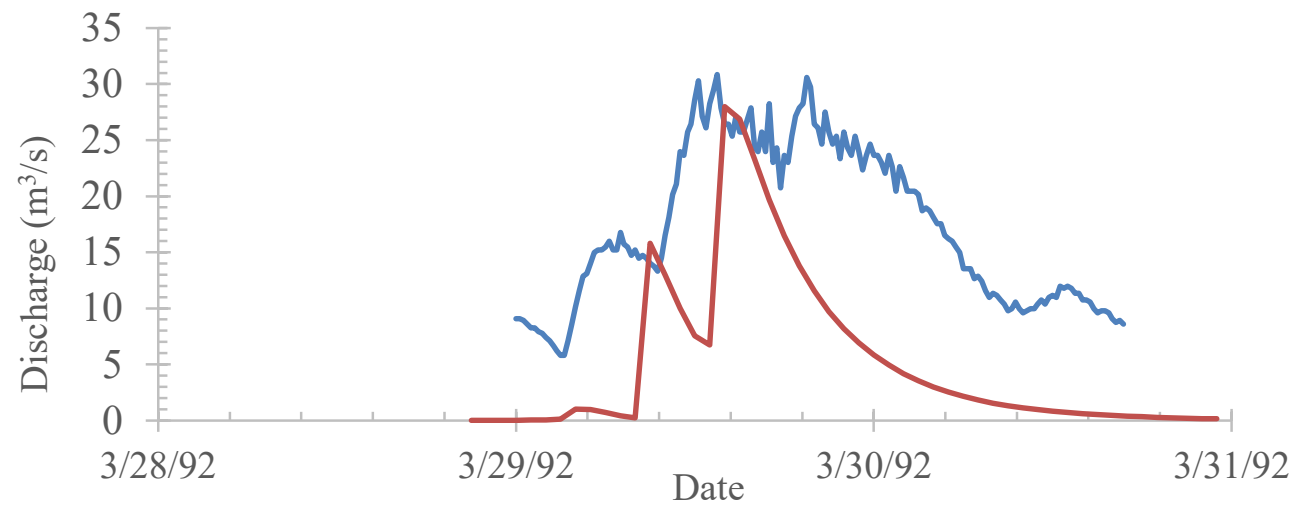

(c) Spring

Figure 14 Comparison of measured and simulated flow hydrographs at Cortaro gauge 


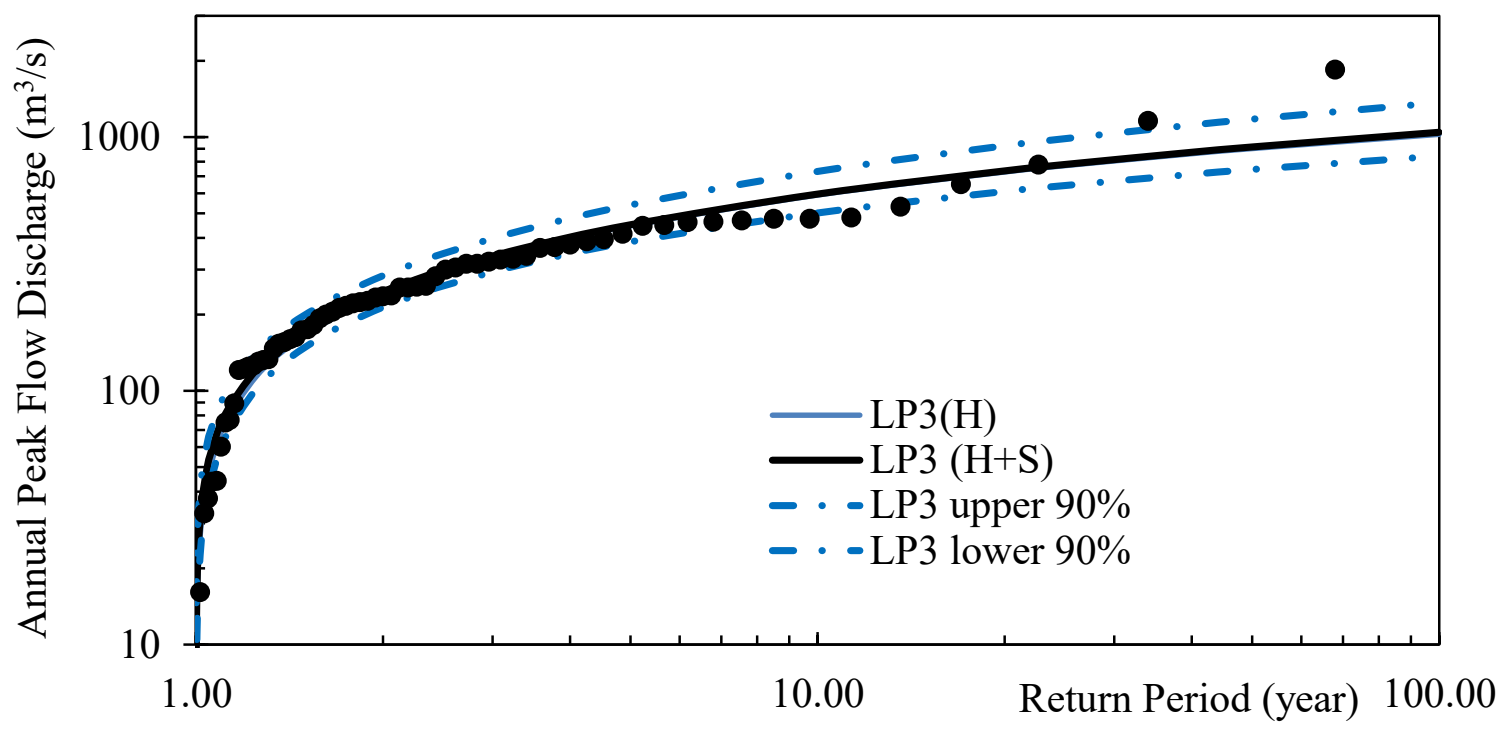

Figure 15 Current and future flood frequency curves for Upper Santa Cruz River at Cortaro following USGS 17B guideline (Solid blue line: current fitted flood frequency curve using historical data from 1940-2013; solid black line: future fitted flood frequency curve using historical data from 1940-2013 and simulated data of 2031-2040 and 20712079; dash dotted blue lines: confident limits at $90 \%$ confidence for future fitted flood frequency curves.) 



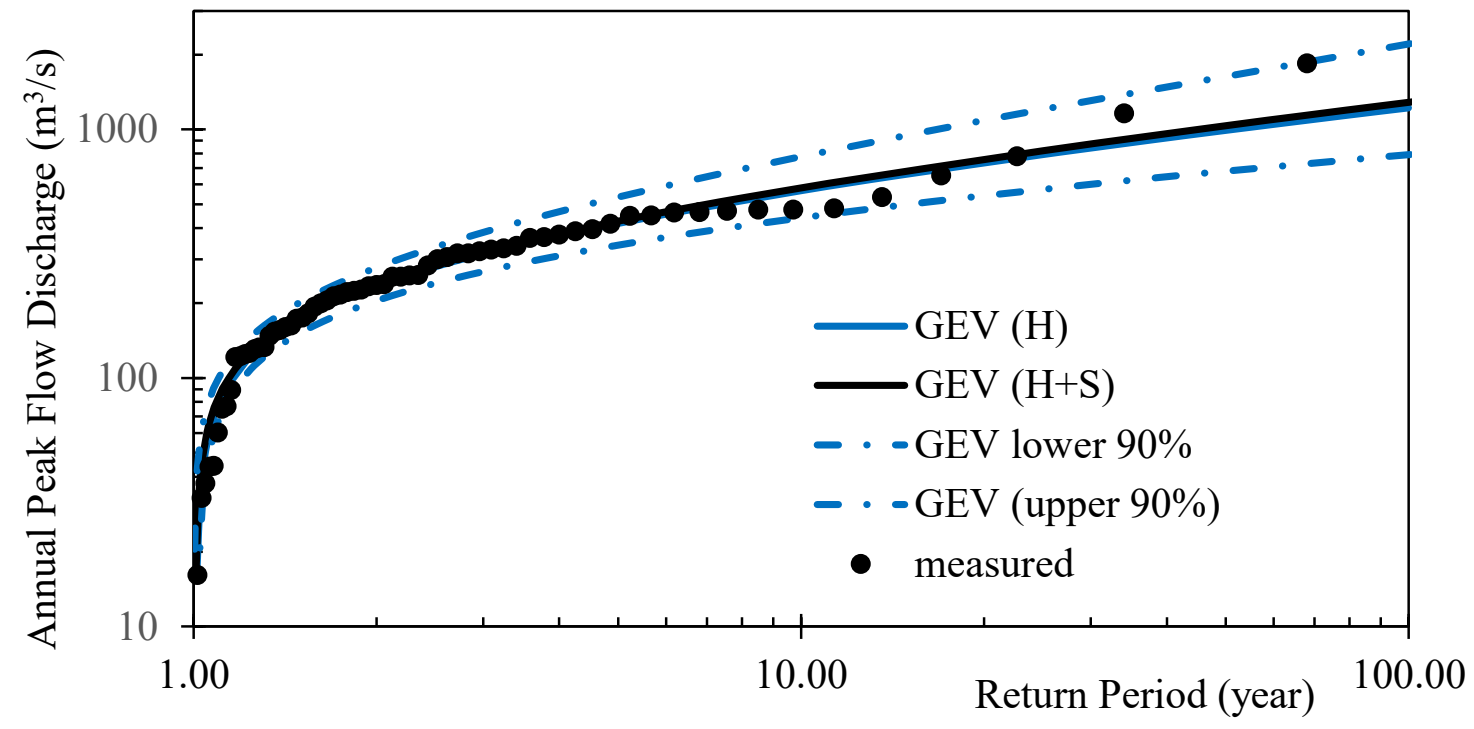

Figure 16 Current and future flood frequency curves for Upper Santa Cruz River at Cortaro following GEV distribution (Solid blue line: current fitted flood frequency curve using historical data from 1940-2013; solid black line: future fitted flood frequency curve using historical data from 1940-2013 and simulated data of 2031-2040 and 2071-2079; dash dotted blue lines: confident limits at $90 \%$ confidence for the future fitted flood frequency curve.) 